\title{
Studies on Chemical Resistance of PET-Mortar Composites: Microstructure and Phase Composition Changes
}

\author{
Ahmed Soufiane Benosman ${ }^{1,2,3^{*}}$, Mohamed Mouli ${ }^{2}$, Hamed Taibi ${ }^{1}$, Mohamed Belbachir ${ }^{1}$, \\ Yassine Senhadji ${ }^{2}$, Ilies Bahlouli ${ }^{1}$, David Houivet ${ }^{4}$ \\ ${ }^{1}$ Faculty of Science, Laboratory of Polymer Chemistry, University of Oran, Es-Senia, Algeria \\ ${ }^{2}$ Department of Civil Engineering, Laboratory of Materials, ENSET, Oran, Algeria \\ ${ }^{3}$ Department of Chemistry, Preparatory School of Science and Technology EPST, Tlemcen, Algeria \\ ${ }^{4}$ University of Caen Basse-Normandie, Laboratory of LUSAC EA 2607, Cherbourg Octeville, France \\ Email: *amre20022000@yahoo.fr
}

Received January 10, 2013; revised February 11, 2013; accepted February 18, 2013

Copyright (C) 2013 Ahmed Soufiane Benosman et al. This is an open access article distributed under the Creative Commons Attribution License, which permits unrestricted use, distribution, and reproduction in any medium, provided the original work is properly cited.

\begin{abstract}
Researches into new and innovative uses of waste plastic materials are continuously advancing. These research efforts try to match society's need for safe and economic disposal of waste materials. The use of recycled plastic aggregates saves natural resources and dumping spaces, and helps to maintain a clean environment. The present articles deals with the resistance to chemical attack of polymer-mortars, which are often used as low-cost promising materials for preventing or repairing various reinforced concrete structures. To gain more knowledge on the efficiency of polymer-mortar composites, four mortar mixtures: one specimen with Portland cement and three mixtures with $2.5,5$, and $7.5 \mathrm{wt} \%$ of the substitution of cement by polyethylene terephthalate (PET) were exposed to the influence of aggressive environment $\left(0.5 \%, 1 \%\right.$ and $1.5 \% \mathrm{HCl}$ acids, $10 \% \mathrm{NH}_{4} \mathrm{Cl}, 5 \% \mathrm{H}_{2} \mathrm{SO}_{4}$ acid and $10 \%\left(\mathrm{NH}_{4}\right)_{2} \mathrm{SO}_{4}$ solutions). The measurements of several properties were carried out, the results were analyzed and the combination of X-ray diffraction, FT-IR spectroscopy, differential thermal analysis (DTA), thermogravimetric (TG) analysis, differential scanning calorimetry (DSC) analysis and the composites were also observed by SEM led to the positive identification of the deterioration products' formation. From this study, it was found that the addition of PET to the modified mortars, means reducing the penetration of aggressive agents. So, the PET-modified mortars exposed to aggressive environments showed better resistance to chemical attack. The new composites appear to offer an attractive low-cost material with consistent properties. The present study highlights the capabilities of the different methods for the analysis of composites and opened new way for the recycling of PET in polymer-mortars.
\end{abstract}

Keywords: Composite; Polymer-Mortar; PET Waste; Acids; $\mathrm{NH}_{4} \mathrm{Cl}$ Attack; Ammonium-Sulfate Attack; Microstructure

\section{Introduction}

Degradation of concrete, as well as the related protection and ensuring of concrete structures against aggressive impacts by chemical agents, regardless of whether this concerns liquid, gas, or even solid phase under certain conditions, represents a complex problem of utmost importance for the economy in general, and especially for building construction and the construction industry [1]. Therefore, polymer-modified mortars have been popular

"Corresponding author. construction materials because of their excellent properties in comparison with ordinary mortars. Polymers have been used for improving mechanical properties, adhesion with substrates, or waterproofing properties of mortars and concretes. The literature agrees that the properties of polymer modified mortar and concrete depend significantly on the polymer content or polymer-cement ratio, that is, the mass ratio of the amount of polymer solids in a polymer-based admixture to the amount of cement in a polymer-modified mortar or concrete [2-4].

A substantial growth in the consumption of plastic is 
observed all over the world in recent years, which has led to huge quantities of plastic-related waste. Recycling of plastic waste to produce new materials like concrete, mortar or composite appears as one of the best solution for disposing of plastic waste, due to its economic and ecological advantages. Several works have been performed or are under way to evaluate the properties of cement-composites containing various types of plastic waste as aggregate, filler or fibre $[5,6]$.

Depending on the appropriate final target, varied types of waste can be used in concrete: Portella et al. [7] and Guerra et al. [8] have studied the properties of concrete with addition of ceramic waste; Ismail and Al-Hashmi [9] have studied concrete with recycled plastic addition; Angulo et al. [10] have characterized recycled materials from construction and demolition as an aggregate for concrete; and, amongst others, Hoppen et al. [11] have found in concrete the possibility to deposit the residual sludge from water treatment stations.

Different works, as of Rebeiz [12], Choi et al. [13,14] and JO et al. [15], have analyzed the effect of addition of recycled PET to the properties of concrete. The fibers of recycled PET easily mix in the concrete, giving new properties to the material [16]. Khaloo et al. [17] have observed that the addition of tire rubber particles provided the concrete with higher ductility in compressive strength testing, if compared with concrete without addition. J. C. A. Galvão et al. [18] have demonstrated a better performance to use of waste polymers (PET, LDPE and rubber from useless tires) in concrete for repair of dam hydraulic surfaces. Wang et al. [19] have analyzed a Performance of cement mortar made with recycled high impact polystyrene, which is a common component of consumer electronics. Corinaldesi et al. [20] have also showed a better mechanical behaviour and thermal conductivity of mortars containing waste rubber particles coming from wasted rubber-shoe outsoles (SR, acronym of "sole rubber"). In the previous work [21,22], the author studied the effects of PET polymer on the mortar properties, specifically to decrease the chloride ion penetration depth and apparent chloride ion diffusion coefficient of polymer-mortar composites. This may be explained due to the reduced volume of large-sized pores and the improved resistance to the absorption of the test solutions with an increase in polymer-cement ratio [22]. In addition, Gouasmi et al. $[23,24]$ showed the improvement of the adherence strength and the resistance to aggressive solutions of composites using waste PET lightweight aggregates (WPLA). One of the advantages of the use of recycled plastic in concrete is the reduction of solid waste in landfills $[5,6]$.

Polyethylene terephthalate (PET) is one of the most common consumer plastics used and is widely employed as a raw material to realize products such as blown bot- tles for soft-drink use and containers for the packaging of food and other consumer goods. PET bottles have taken the place of glass bottles as storing vessel of beverage due to its lightweight and easiness of handling and storage.

In 2007, it is reported a world's annual consumption of PET drink covers of approximately 10 million tons, which presents perhaps 250 milliards bottles. This number grows about up to $15 \%$ every year [25]. On the other hand, the number of recycled or returned bottles is very low. Generally, the empty PET packaging is discarded by the consumer after use and becomes PET waste (WPET). The major problems that this level of waste production generates initially entail storage and elimination [26]. The recycling of PET bottles and the preservation of natural resources are priority items but to date, the recycling of PET bottles as a lightweight aggregate for concrete has not been studied because of the high melting cost [16].

Chemical degradation of concrete is the consequence of reactions between the constituents of cement stone, i.e., calcium silicates, calcium aluminates, and above all calcium hydroxide, as well as other constituents, with certain substances from water, solutions of soil, gases, vapors, acids etc. The most important aggressive agents are: $\mathrm{SO}_{4}^{2-}, \mathrm{Mg}^{2+}, \mathrm{NH}_{4}^{+}, \mathrm{Cl}^{-}, \mathrm{H}^{+}$, and $\mathrm{HCO}_{3}^{-}[1,27,28]$.

When speak about sulfate degradation, we primarily think of the impact by sulfate ions on cement stone. The sulfate ion is the cause of one of the most dangerous corrosions - the corrosion of expansion and swelling-because it causes the occurrence of expansive com- pounds, the most important of which is ettringite,

$\mathrm{C}_{3} \mathrm{~A} \cdot 3 \mathrm{CaSO}_{4} \cdot 32 \mathrm{H}_{2} \mathrm{O}$, in the shape of prismatic crystals [29,30].

For the process of concrete degradation under the impact of sulfates, it is essential which cation is linked with the sulfate ion. Namely, cations linked with sulfate ions can be divided into three characteristic groups [1]. The first group includes alkali metals $\mathrm{Na}^{+}$and $\mathrm{K}^{+}$, which give extremely soluble hydroxides, while the second group comprises metals such as $\mathrm{Mg}^{2+}$ and $\mathrm{Fe}^{2+}$, which give poorly soluble hydroxides, and the third group consists of cations $\mathrm{NH}_{4}^{+}$and $\mathrm{H}^{+}$, which give volatiles or hydroxide. The third group of sulfates, that is $\left(\mathrm{NH}_{4}\right)_{2} \mathrm{SO}_{4}$ and $\mathrm{H}_{2} \mathrm{SO}_{4}$, covers the most aggressive compounds. In case of impact by these compounds on concrete, there occurs not only expansion, but also intensive dissolution of cement stone [1].

The degree of aggressivity of an acid is dependent on the chemical character of anions present. The strength of acid, its dissociation degree in solutions and, mainly, the solubility of the salt formed are dependent on the chemical character of anion. With respect to concrete acidic attack, the solubility of calcium salts formed is of a great 
significance. Because the acidic attack is based on the processes of decomposition and leaching of the constituents of cement matrix, the conditions of transport phenomena, such as the supply of aggressive acidic solutions and draining of the products of the attack is of specific significance for the intensity of attack [31-33].

In addition, a parameter which is tightly connected with the properties of acids is that their $\mathrm{pH}$ reaches a value of approximately 5 and lower. The severity of the acidic attack is significantly dependent on the solubility of the calcium salt formed. In the case of the formation of highly soluble salts, the severity of the attack is very high. This is caused by the dissolving and leaching of the formed salt from the attacked material. A very porous layer of corrosive products remains on the surface, contributing to further development of the deterioration process. In the case of the formation of insoluble calcium salts such as calcium oxalate and sulfate the effect of the acidic solution is entirely different. A dense insoluble layer is formed enhancing the development of the acidic attack showing a protective effect. This is used in practice for the protective purposes [34].

The objective of the research reported here was to evaluate the chemical resistance of polymer-mortar composites containing a waste polyethylene terephtalate PET, as a substitute of the cement used in the mix, under hydrochloric acid, ammonium-chloride, ammonium-sulfate and sulfuric acid solutions exposure. The identification of the deterioration products' which appear on the surface of the samples were analyzed by X-ray diffraction, FTIR, SEM, ATD, TG/dTG and DSC analyses. However, no pertinent data were previously found concerning the effect of PET against ammonium-chloride or ammoniumsulfate attack. So, in this paper the durability of PETmortar composites exposed to aggressive solutions has been investigated. If successful, such an application of waste PET, as substitute of cement, will be a major step towards reducing the solid waste disposal problem and reliance on natural resources, thereby reducing environmental pollution and energy consumption. Additionally, the immediate consequence is the anticipated necessity of maintenance and repairs of the concrete structures, which must have specific characteristics, mainly mechanical and chemical, based on the material of the base or its substratum.

\section{Materials, Experimental Design and Methods}

\subsection{Raw Materials}

The cement used was a blended Portland cement type CPJ-CEM II/A (pouzzolanic cement) delivered from Zahana factory located in the western Algeria, chemical and physical properties of cement are shown in Tables 1 and 2, respectively, according to the manufactories. The chemical composition was obtained by using an X-ray fluorescence spectrometer analysis type OXFORD MD $\mathrm{X}^{1000}$.

Two different aggregate types were selected for this study, sand (S) and PET particles. Those come from drinking water bottles that was first separated, washed and shredded. The particles thus derived were then shredded once again, using a propeller crusher in order to control granular limit with crushing. Moreover, they present irregular shape and rough surface texture in order to facilitate matrix-particles adhesion (Figure 1). Figure $\mathbf{2}$ showed the X-ray diffraction analysis of PET particles and indicated the presence of a backbone form of the polymer which generates sharp peaks at a high angle range $\sim 10^{\circ}-35^{\circ}$. The main mechanical and thermal properties of the plastic used in this study are presented in Table 3. Particle size distributions analysis (Figure 3) reveals the sand to be particularly coarse (Fineness modules $=3.66)$ and that the upper granular limit value of PET aggregates is $5 \mathrm{~mm}$. After preliminary tests, polymer particles of size lower than $1 \mathrm{~mm}$ were used in this study. Absolute density of PET particles $\left(1.35 \mathrm{~g} / \mathrm{cm}^{3}\right)$ is approximately 2.5 times smaller than that of cement

Table 1. Cement chemical composition.

\begin{tabular}{cccccc}
\hline \multicolumn{7}{c}{ Oxide analysis $(\%)$} \\
\hline Loss on ignition & 2.08 & $\mathrm{Fe}_{2} \mathrm{O}_{3}$ & 4.57 & $\mathrm{SO}_{3}$ & 1.85 \\
$\mathrm{SiO}_{2}$ & 21.83 & $\mathrm{CaO}$ & 63.42 & $\mathrm{CaO}$ free & 0.25 \\
$\mathrm{Al}_{2} \mathrm{O}_{3}$ & 6.01 & $\mathrm{MgO}$ & 0.22 & & \\
\hline
\end{tabular}

Table 2. Physical properties of cement.

\begin{tabular}{cc}
\hline \multicolumn{2}{c}{ Physical properties } \\
\hline Setting time $(\mathrm{min})$ & 120 \\
Initial & 200 \\
Final & 2977 \\
Blaine surface area $\left(\mathrm{cm}^{2} / \mathrm{g}\right)$ & 3.09 \\
Absolute density $\left(\mathrm{g} / \mathrm{cm}^{3}\right)$ & 32.5 \\
\hline
\end{tabular}

Table 3. Physical properties of the PET plastic used.

\begin{tabular}{cc}
\hline Physical properties & \\
\hline Tensile strength at break $(\mathrm{MPa})$ & 70 \\
Elongation at break $(\%)$ & 70 \\
Flexural modulus (rigidity) $(\mathrm{MPa})$ & 2.0 \\
Tensile modulus $(\mathrm{GPa})$ & 2.9 \\
Melting point $\left({ }^{\circ} \mathrm{C}\right)$ & 260 \\
Water absorption $(\%)$ & 0 \\
\hline
\end{tabular}




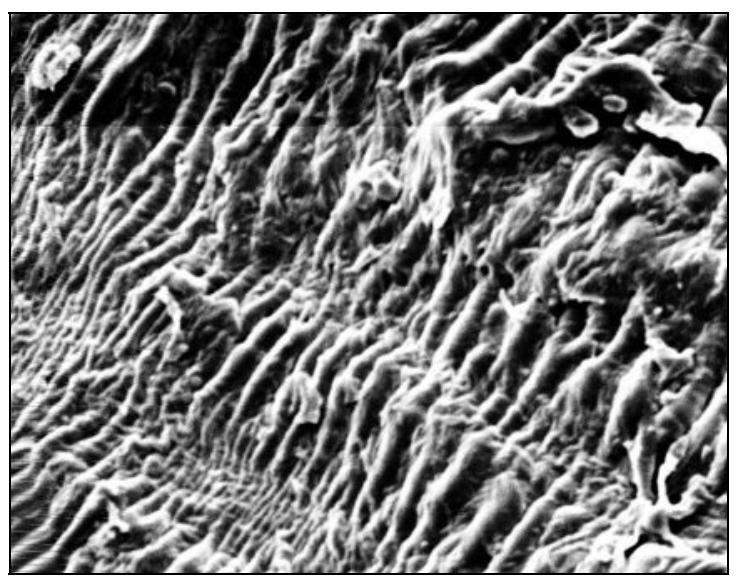

Figure 1. Scanning electron micrographs of PET particles, (magnification, $\times 1200$ ).

$\left(3.09 \mathrm{~g} / \mathrm{cm}^{3}\right)$. This low density will allow the lightening of PET-mortar composite.

\subsection{Composite Mixing Conditions}

The mortar manufactured with PET particles was first optimized on the basis of mechanical criteria and then constitutes the reference composite. The composites containing PET particles were produced in accordance with the results of the previous work [35]. A massic ratio of 3 between sand (S) and the cement (C) has been respected. Various massic percentages of cement $(2.5 \%$, $5.0 \%$ and $7.5 \%$ ) were substituted by the same weight of granulated plastic waste (Table 4). The water to binder ratio was kept constant at 0.5 . The physical properties of the pastes of mortars were determined in accordance with EN 19-3 [36].

The PET particles and cement were first dry-mixed at $140 \mathrm{rpm}$ during $1 \mathrm{~min}$ in a standard mixing machine (EN 196-1 [37]) to reach a homogeneous mixture. Then sand was added and the mixing continues during $1 \mathrm{~min}$ at low speed. Next, water was gradually added at $140 \mathrm{rpm}$ during $1 \mathrm{~min}$ and after the whole is mixed during $1 \mathrm{~min}$ with $285 \mathrm{rpm}$. After pouring fresh material into the molds, samples were stored in both a hygrometrically-controlled and temperature-controlled room ( $98 \%$ relative humidity and $20^{\circ} \mathrm{C} \pm 2^{\circ} \mathrm{C}$ ) for $24 \mathrm{~h}$. After removal from the moulds, at $24 \mathrm{~h}$ of age, mortar specimens were immersed in water saturated with lime at $20^{\circ} \mathrm{C} \pm 3^{\circ} \mathrm{C}$ until the age of testing. Test results from the Table 4 of the hydraulic transport properties, sorptivity-value, revealed that the addition of PET particles tends to restrict water propagation in the cement matrix and reduces water absorption of the composite. This may be due both to the capability of PET to repel water (non-sorptive nature, water absorption $\%=0$, Table 3) and to the increase of air-entrainment, as manifested by closed empty pores, which are not accessible to water. This phenomenon serves to reduce the volume accessible to water and hence capillary porosity. The decrease in water absorption is also attributed to a reduction in the porosity near particle/matrix interfacial zone, due to the high bonding between PET additive and cement paste [35]. So, the decrease of the sorptivity-value is favorable to the durability of the specimen structures.

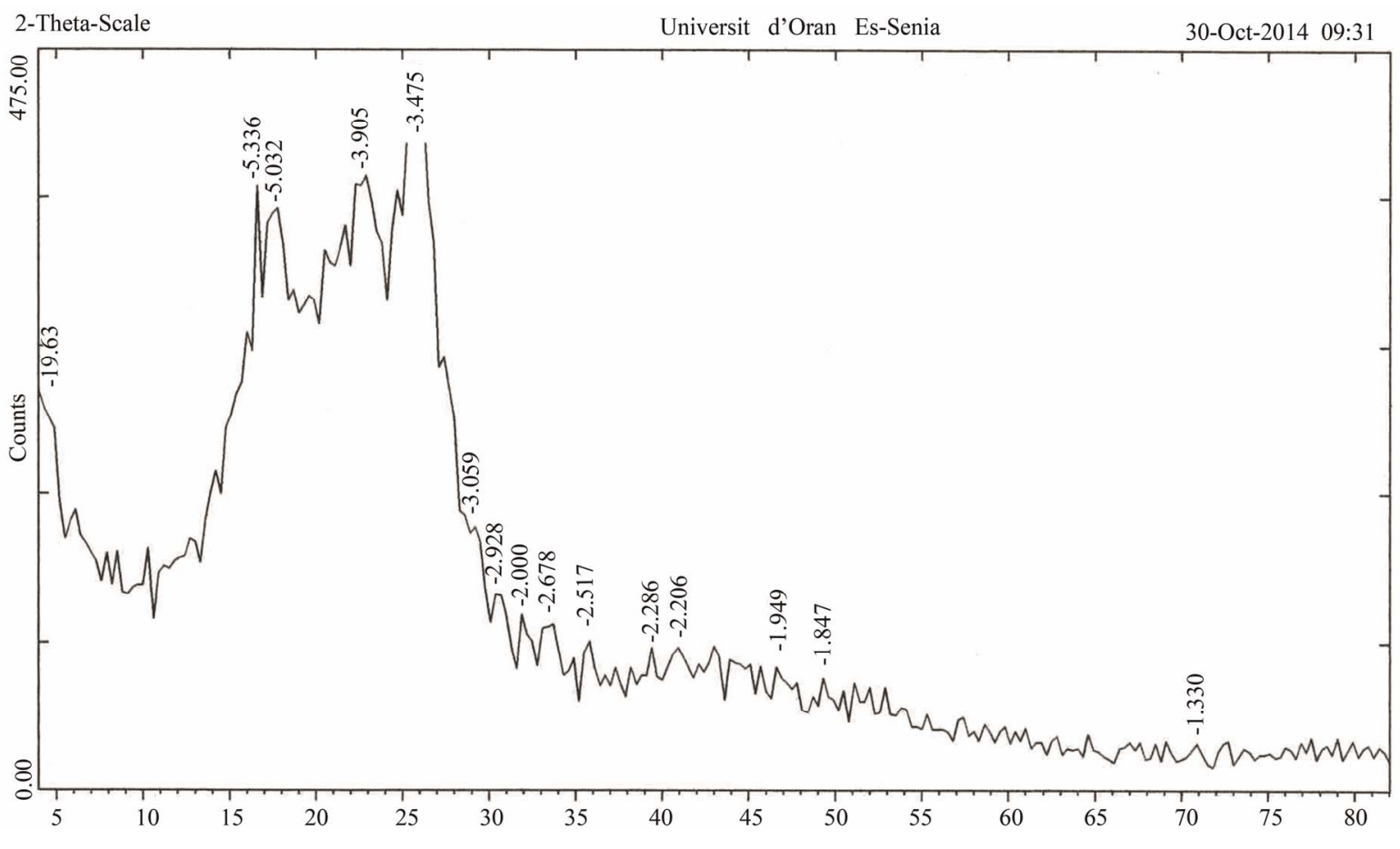

Figure 2. X-ray diffraction pattern of the PET particles. 


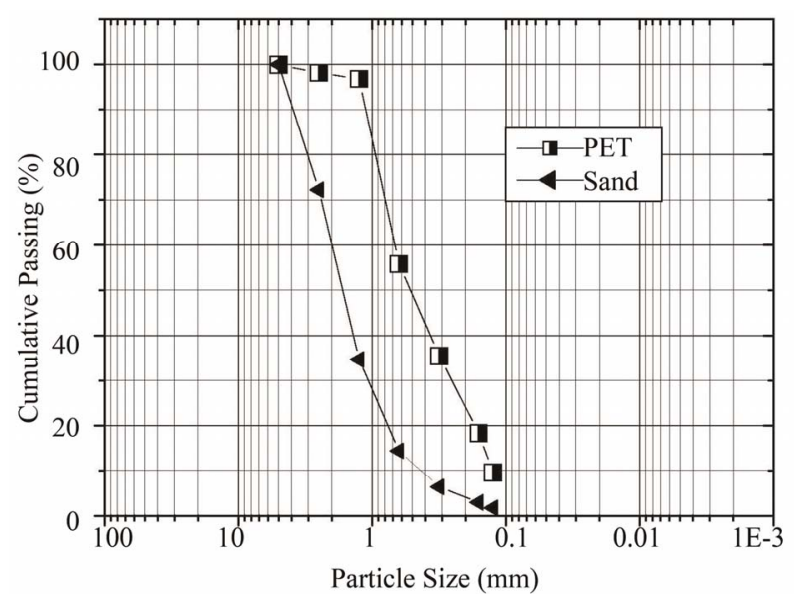

Figure 3. Particle size distributions of polyethylene terephthalate (PET) and Sand.

\subsection{Resistance to Chemical Attack Test}

The relative acid attack was determined in accordance with ASTM C267-97 [38]. The mortar specimens were cured in water at $20^{\circ} \mathrm{C} \pm 3^{\circ} \mathrm{C}$ for 28 days before being subjected to acid attack. Three specimens of each mortar and composite mixes $\left(50 \times 50 \times 50 \mathrm{~mm}^{3}\right)$ were immersed in three types of chemical solutions: $10 \%$ ammonium chloride $\mathrm{NH}_{4} \mathrm{Cl} ; 10 \%$ ammonium-sulfate $\left(\mathrm{NH}_{4}\right)_{2} \mathrm{SO}_{4} ; 5 \%$ sulfuric acid $\mathrm{H}_{2} \mathrm{SO}_{4}$. Before the test, the attacked specimens were cleaned with deionised water and then the acid attack was evaluated by measuring the mass loss $(M L)$ of the specimens, determined as follows:

$$
\operatorname{ML}(\%)=\frac{W_{r}-W_{s}}{W_{r}} \times 100
$$

where $W_{r}$ is weight of the specimen before immersion and $W_{s}$ is weight of the cleaned immersed specimen after test period. The solution was renewed every 7 days and the mass loss of the specimens measured.

After immersion in $0.5 \%, 1 \%$ and $1.5 \% \mathrm{HCl}$ acids $\left(4 \times 4 \times 16 \mathrm{~cm}^{3}\right), 5 \% \mathrm{H}_{2} \mathrm{SO}_{4}$ acid (ASTM C267-97) and $10 \%\left(\mathrm{NH}_{4}\right)_{2} \mathrm{SO}_{4}$ solutions (ASTM C1012-04 [39]) for the required period of time, the specimens were capped and tested for residual compressive strength based on the original cross-sectional area. The compressive strength loss $(C S L \%)$ is calculated as follows:

$$
\operatorname{CSL}(\%)=\frac{f_{c r}-f_{c s}}{f_{c r}} \times 100
$$

where $f_{c r}$ is the reference compressive strength of specimen before immersion in the acid or sulphate solutions in $\mathrm{MPa}$ and $f_{c s}$ is the average compressive strength of the specimens after immersion in acid or sulphate solutions for the required period of time.

After compression testing, scanning electron microscopy (SEM), X-ray diffraction (XRD), FT-IR analyses, DSC and DTA-TGA/dTG were conducted on selected surface fractures to investigate damage mechanisms.

An accelerated leaching test using an ammonium chloride solution $\left(10 \% \mathrm{NH}_{4} \mathrm{Cl}\right)$ was carried out on three samples $\left(50 \times 50 \times 50 \mathrm{~mm}^{3}\right)$ of each composite, after cured in water at $20^{\circ} \mathrm{C} \pm 3^{\circ} \mathrm{C}$ for 28 days. Ammonium nitrate allows an equivalent leaching test with demineralised water to be simulated but increases the kinetics by a factor $100[40,41]$. The mortar and composites specimens were immersed in the solution at $20^{\circ} \mathrm{C}$ for 480 days. For the required time of test, the leached depth (observed with phenolphthalein) and the mass loss were measured each time of test.

\section{Results and Discussion}

\subsection{Hydrochloric Acid (HCl) Attack}

\subsubsection{Compressive Strength Loss (CSL\%)}

Mass loss is a simple traditional test in the context of acid attack. However, mass change results may depend on sample size and cement type, and are also influenced by the way the decomposed cement paste and other reaction products on samples are treated during testing [42, 43]. Therefore, along with mass loss test, compressive strength is considered to be a more reliable measure to judge the performance of mortar/concrete subjected to acid attack. Siad et al. [44] reported that there is some divergence between the mass loss and the compressive strength loss.

Table 4. Mix proportions and physical properties of polymer-mortar composites.

\begin{tabular}{ccccccc}
\hline Polymer-Cement Ratios (\%) & Setting Time (min) & $\begin{array}{c}\text { Water demand } \\
\text { for Standard } \\
\text { Consistency }(\%)\end{array}$ & Density $\left(\mathrm{g} / \mathrm{cm}^{3}\right)$ & $\begin{array}{c}\text { Compressive strength (MPa) } \\
\text { Capillary Coefficient } \\
\text { E-05 }\left(\mathrm{cm}^{2} / \mathrm{sec}\right)\end{array}$ \\
\hline & Initial & Final & & 28 days & 28 days \\
2.5 & 120 & 200 & 24 & 2.28 & 41.6 & 3.89 \\
5.0 & 125 & 205 & 24.5 & 2.23 & 3.6 & 3.50 \\
7.5 & 130 & 210 & 25 & 2.22 & 32.5 & 2.85 \\
\hline
\end{tabular}


Hence, Figure 4 presents the results of compressive strength loss $C S L \%$ of the mixes at 56 days in different hydrochloric acid concentration $(0.5 \%, 1 \%$ and $1.5 \%)$ solutions. The results indicate that the resistance of acidic attack of the composites (PET7.5) was increased with an increase in PET content. At day-56, the CSL\% of PET7.5 was reduced by $68 \%, 41 \%, 10.7 \%$ for the $0.5 \%, 1 \%$ and $1.5 \%$ of $\mathrm{HCl}$ acid solutions, respectively, when compared to that of PET0.

The $\mathrm{H}_{2} \mathrm{SO}_{4}$ solutions lead to the formation of less water-soluble gypsum $\mathrm{CaSO}_{4}, 0.241 \mathrm{~g} / 100 \mathrm{ml}$ of $\mathrm{H}_{2} \mathrm{O}$ at $20^{\circ} \mathrm{C}$, and ettringite on the surface in contact with the cementing matrix. With $\mathrm{CH}_{3} \mathrm{COOH}$ acid, there is a formation of the hydrate calcium acetate $\mathrm{Ca}\left(\mathrm{CH}_{3} \mathrm{COO}\right)_{2}$, $52.0 \mathrm{~g} / 100 \mathrm{ml}$ of $\mathrm{H}_{2} \mathrm{O}$. While, the chemicals formed as the products of reaction between hydrochloric acid and hydrated cement phases are some soluble salts, mostly with calcium chloride $\mathrm{CaCl}_{2}$ (dihydrate) that is very watersoluble: $46.08 \mathrm{~g} / 100 \mathrm{ml}$ of $\mathrm{H}_{2} \mathrm{O}$, which are subsequently leached out, and some insoluble salts along with amorphous hydrogels (iron hydroxide) which remain in the corroded layer. These chemical reactions are shown in Equations (3)-(5). These results are in agreement with those reported by elsewhere [45-47].

$$
\begin{aligned}
& 2 \mathrm{HCl}+\mathrm{Ca}(\mathrm{OH})_{2} \\
& \rightarrow \mathrm{CaCl}_{2} \cdot 2 \mathrm{H}_{2} \mathrm{O}(\text { hydrate calcium chloride }) ; \\
& \mathrm{H}_{2} \mathrm{SO}_{4}+\mathrm{Ca}(\mathrm{OH})_{2} \rightarrow \mathrm{CaSO}_{4} \cdot 2 \mathrm{H}_{2} \mathrm{O}(\text { gypsum }) ; \\
& 3 \mathrm{CaSO}_{4}+3 \mathrm{CaO} \cdot \mathrm{Al}_{2} \mathrm{O}_{3} \cdot 6 \mathrm{H}_{2} \mathrm{O}+25 \mathrm{H}_{2} \mathrm{O} \\
& \rightarrow 3 \mathrm{CaO} \cdot \mathrm{Al}_{2} \mathrm{O}_{3} \cdot 3 \mathrm{CaSO}_{4} \cdot 31 \mathrm{H}_{2} \mathrm{O}(\text { ettringite })
\end{aligned}
$$

Additionally, these results are confirmed by the change of surface samples before and after immersion in the $\mathrm{HCl}$

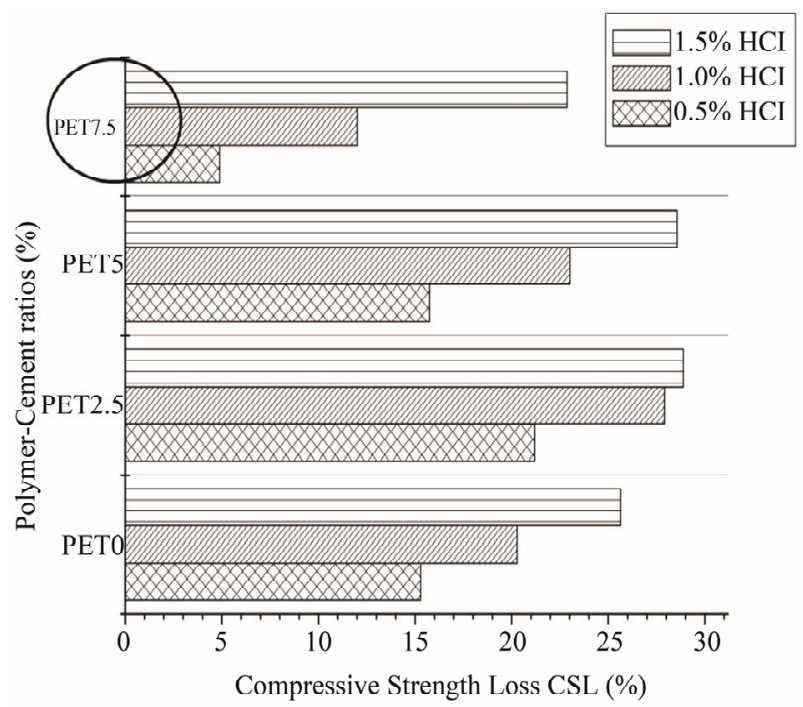

Figure 4. Compressive strength loss of specimens under $\mathrm{HCl}$ acid solutions exposure. aggressive solutions as depicted in Figure 5. These mortars kept their rectangular forms more or less, but their dimensions decreased considerably from $0.5 \%, 1 \%$ to $1.5 \%$. Hydrochloric acid attack is a typical acidic corrosion which can be characterized by the formation of layer structure [47]; its can be divided to three main zones: undamaged zone, hydroxide mixture zone or brown ring, and attacked zone. By hydroxide mixture zone, there is a layer formed by undissolved salts seen as a dark brown ring.

The chemical resistance of materials is more or less affected by the concentration and the nature of acids in the order with the most aggressive as given below:

$$
0.5 \% \mathrm{HCl}<1.0 \% \mathrm{HCl}<1.5 \% \mathrm{HCl} \text {. }
$$

The increase in the resistance to hydrochloric attack of the composites is attributed to the impervious PET granules blocking the passage of the aggressive solutions and the reduction of the sorptivity of PET-mortar composites (Tables 3 and 4). Furthermore, the decrease in porosity due to the incorporation of PET in modified mortars [48] contributes to reduce the absorption of acidic solution accompanied by a reduction of loss in weight. These results are in agreement with those reported by Benosman et al. [46]. Additionally, different teams of researchers [49-51] reported that the incorporation of organic additions (polymers) increases chemical resistance in aggressive media.

\subsubsection{X-Ray Diffraction (XRD) Analysis}

Figure 6 presents the XRD analysis of composite PET0, as an example, before and after attack by different hydrochloric acid concentration $(0.5 \%, 1 \%$ and $1.5 \%)$ solu

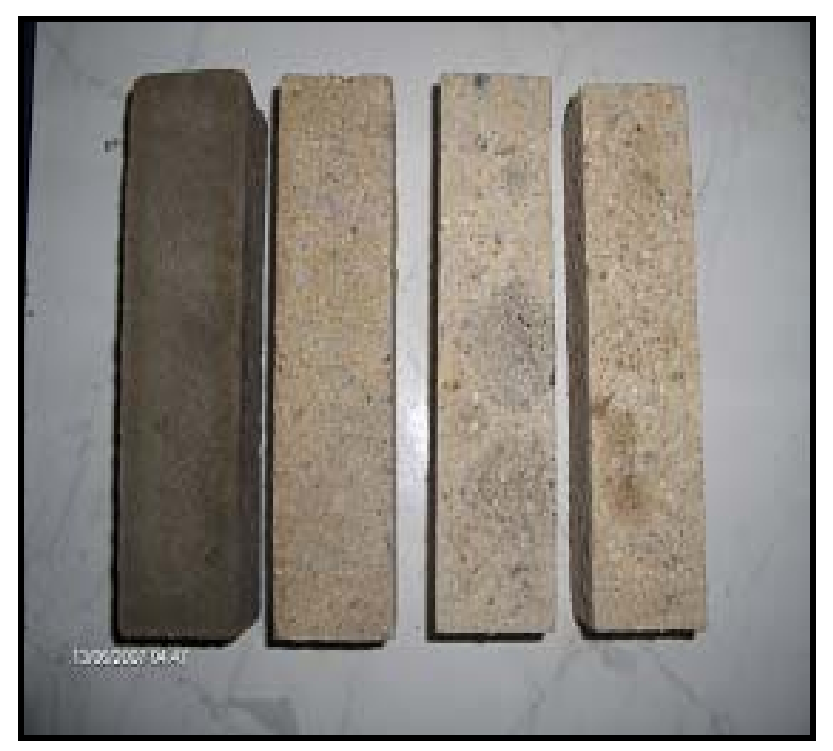

Figure 5. Deterioration of specimens after 56 days of immersion; (1) Tap water, (2) $0.5 \%$, (3) $1 \%$, (4) $1.5 \% \mathrm{HCl}$ acids (From the left to right, respectively). 


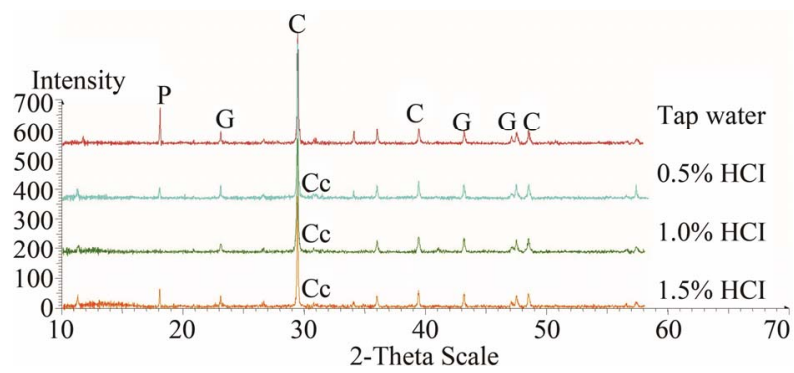

Figure 6. X-ray diffraction pattern of the specimens under $\mathrm{HCl}$ acids exposure. $\mathrm{P}$ : portlandite $\mathrm{Ca}(\mathrm{OH})_{2}$, C: calcite, G: gypsum, $\mathrm{Cc}: \mathrm{CaCl}_{2} \cdot 2 \mathrm{H}_{2} \mathrm{O}$ (hydrated calcium chloride).

tions. The stacking of the various spectra (initial state, after $0.5 \%$ attack, after $1 \%$ attack and after $1.5 \%$ attack) confirms the appearance of a trace of calcium chloride $\left(\mathrm{CaCl}_{2}\right)$ on the specimens exposed to hydrochloric acid. The low quantity of calcium chloride found is due to its high solubility in water $\left(46.08 \mathrm{~g} / 100 \mathrm{ml}\right.$ of $\left.\mathrm{H}_{2} \mathrm{O}\right)$. Washing of each specimen after the immersion period leaves its surface nearly free from this salt. Additionally, the portlandite $\mathrm{Ca}(\mathrm{OH})_{2}$ was decomposed by different acids concentration following the chemical reaction (Equation (3)).

\subsubsection{FT-IR Analyses}

Table 5 illustrates the positions and intensities of infrared absorption bands and Figure 7 shows the FT-IR patterns of specimens exposed to: Tap water, $0.5 \%, 1 \%$ and
$1.5 \% \mathrm{HCl}$ acids solution. The FT-IR spectra of the composite hydrated up to 56 days and cured in water are presented in Figure 7 and Table 5. The major changes of the FT-IR spectra in the hydrated cement pastes are: Calcium hydroxide bands $\left(\sim 3635 \mathrm{~cm}^{-1}\right)$ and also for the free $\mathrm{OH}$ groups, combined and adsorbed water of $\mathrm{CSH}, \mathrm{AFm}$ and AFt phases $\left(\sim 3480 \mathrm{~cm}^{-1}\right)$, molecular water (3440 3446 and $\left.1614-1621 \mathrm{~cm}^{-1}\right)$, carbonate phases $(\sim 1425$, 870.03 and $708 \mathrm{~cm}^{-1}$ ). The broad band at $\sim 1020-1016$ $\mathrm{cm}^{-1}$ arises from C-S-H vibrations, in agreement with those reported by Martinez-Ramirez [52].

As the same for the X-ray diffraction, the FT-IR analysis of composite after attack by different acids (Table 5, Figure 7) confirms the appearance of a trace of calcium chloride $\left(\mathrm{CaCl}_{2}\right)$ on the specimens exposed to various $\mathrm{HCl}$ acids. The low quantity of calcium chloride found is due to its high solubility in water.

Therefore, in Table 5 and Figure 7 no absorption bands corresponding to calcium hydroxide were detected in all of specimens exposed to acidic solutions, which is in agreement with XRD analysis. The $\mathrm{Ca}(\mathrm{OH})_{2}$ was consumed by different $\mathrm{HCl}$ acids following the chemical reaction (Equation (3)).

\subsubsection{DTA-TGA/dTG Analyses}

The simultaneously traced DTA-TGA curves of PET0 composite before and after $\mathrm{HCl}$ acids attack $(0.5 \%, 1 \%$ and 1.5\%) are presented in Figures 8-11.

Table 5. Fourier-transform infrared table of composite before and after attack by different $\mathrm{HCl}$ acids, in $\mathrm{KBr}$ pellet.

\begin{tabular}{|c|c|c|c|c|}
\hline \multicolumn{5}{|c|}{ Positions and Intensities of Infrared Absorption Bands (FT-IR) } \\
\hline$\left(\mathrm{cm}^{-1}\right)$ & Group & Compounds & Tap water & $\mathrm{HCl}(0.5 \%, 1 \%$ and $1.5 \%)$ \\
\hline$\sim 3000-3700$ & $\mathrm{H}_{2} \mathrm{O}, \mathrm{OH}$, hydrogen bonds & Gypsum, CSH & +++ & + \\
\hline$\sim 3636$ (Fine) & $\mathrm{H}_{2} \mathrm{O}, \mathrm{OH}$, hydrogen bonds & portlandite & +++ & --- \\
\hline $3450-3485$ & $\mathrm{H}_{2} \mathrm{O}, \mathrm{OH}$ & $\mathrm{AFm}, \mathrm{AFt}$ & ++ & + \\
\hline $1614-1621$ & $\mathrm{H}_{2} \mathrm{O}, v \mathrm{O}-\mathrm{H}$ & $\mathrm{H}_{2} \mathrm{O}$ & + & + \\
\hline $1425-1433$ & $v \mathrm{C}-\mathrm{O}$ & $\mathrm{CaCO}_{3}$ (Calcite) & + & + \\
\hline $869-874$ & $v \mathrm{C}-\mathrm{O}$ & $\mathrm{CaCO}_{3}$ (Calcite) & + & + \\
\hline $705-710.6$ & $v \mathrm{C}-\mathrm{O}$ & $\mathrm{CaCO}_{3}$ (Calcite) & + & + \\
\hline$\sim 1015-1029$ & $v \mathrm{Si}-\mathrm{O}$ & $\mathrm{CSH}$ vibrations & + & + \\
\hline$\sim 470-524 ; 535$ & $v \mathrm{Ca}-\mathrm{Cl}$ & $\mathrm{CaCl}_{2} \cdot 2 \mathrm{H}_{2} \mathrm{O}$ & 0 & +++ \\
\hline$\sim 2970$ & $v \mathrm{C}-\mathrm{O}$ (harmonic bands) & $\mathrm{CaCO}_{3}$ (Calcite) & + & + \\
\hline $2865-2871$ & $v$ C-O (harmonic bands) & $\mathrm{CaCO}_{3}$ (Calcite) & + & + \\
\hline $2512-2518$ & $v \mathrm{C}-\mathrm{O}$ (harmonic bands) & $\mathrm{CaCO}_{3}$ (Calcite) & + & + \\
\hline$\sim 1799$ & $\nu$ C-O (harmonic bands) & $\mathrm{CaCO}_{3}$ (Calcite) & + & + \\
\hline
\end{tabular}

AFt: $\mathrm{C}(\mathrm{A}, \mathrm{F}) \cdot 3 \mathrm{CaSO}_{4} \cdot 32 \mathrm{H}_{2} \mathrm{O} ; \mathrm{AFm:} \mathrm{C}_{3} \mathrm{~A} \cdot 3 \mathrm{CaSO}_{4} \cdot 12 \mathrm{H}_{2} \mathrm{O}$. 


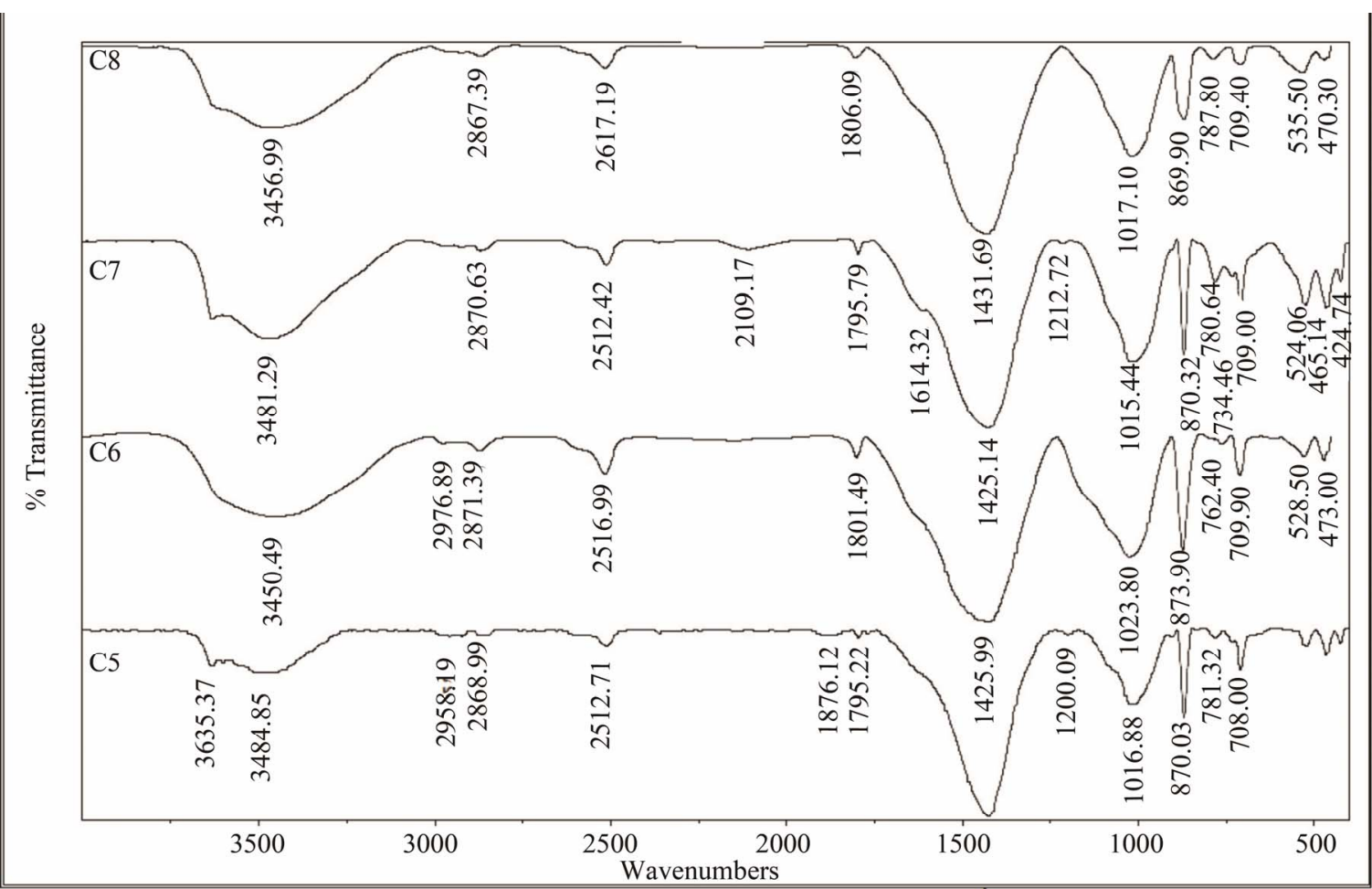

Figure 7. FT-IR spectra of the specimens under HCl acid exposure, (C5: Tap water, C6: 0.5\%, C7: 1\%, C8: 1.5\%).

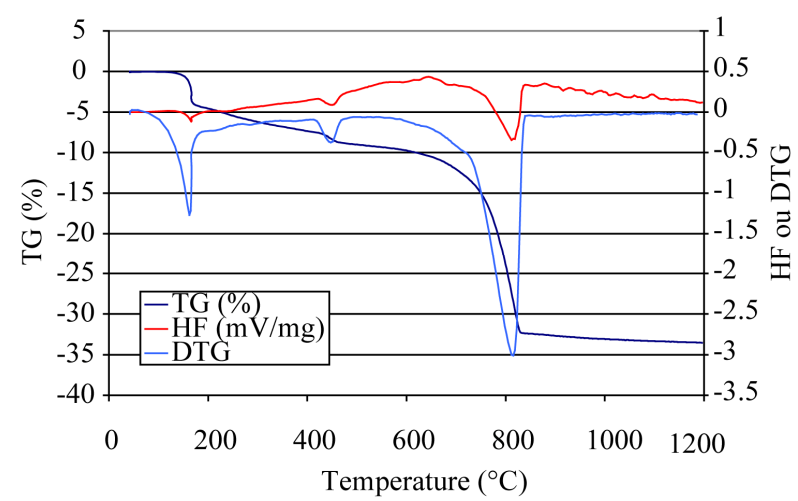

Figure 8. DTA/TG curves at $20 \mathrm{~K} / \mathrm{min}$ of composite PET0 in tap water exposure.

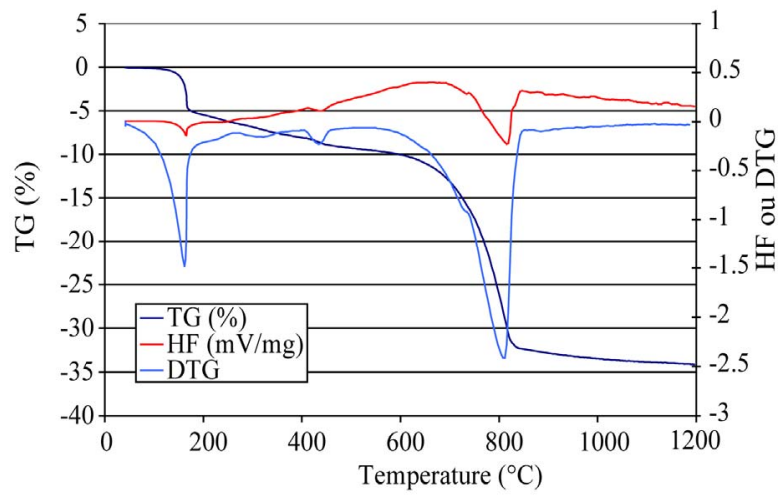

Figure 9. DTA/TG curves at $20 \mathrm{~K} / \mathrm{min}$ of composite PET0 under $0.5 \%$ hydrochloric acid exposure.

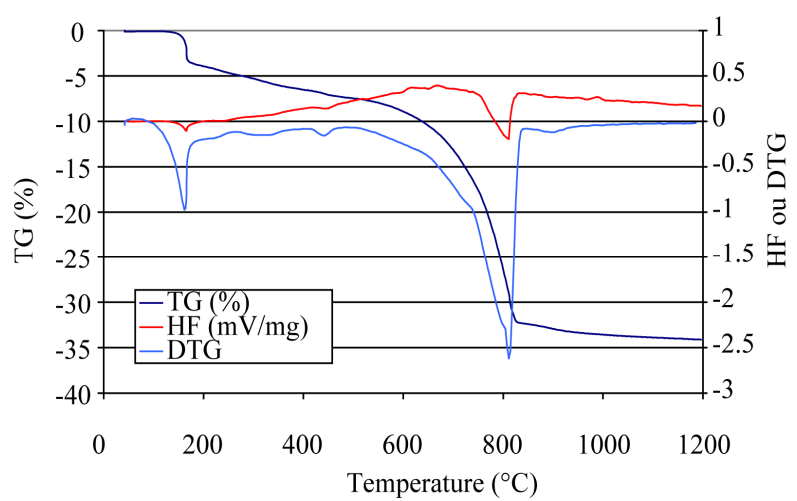

Figure 10. DTA/TG curves at $20 \mathrm{~K} / \mathrm{min}$ of composite PET0 under $1.0 \%$ hydrochloric acid exposure.

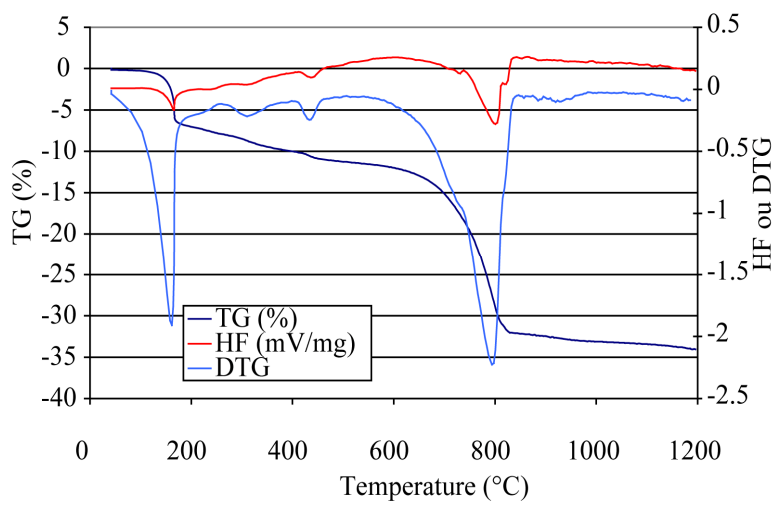

Figure 11. DTA/TG curves at $20 \mathrm{~K} / \mathrm{min}$ of composite PET0 under $1.5 \%$ hydrochloric acid exposure. 
Figure 8 shows the DTA/TG curves of mortar without polymer PET0 in the tap water. It can be seen that DTA-TG/dTG curves for this mortar consist of four zones:

$\sim 100^{\circ} \mathrm{C}-150^{\circ} \mathrm{C}$ : dehydration of pore water $(\mathrm{CSH}$, ettringite),

$\sim 225^{\circ} \mathrm{C}-230^{\circ} \mathrm{C}$ : dehydration of calcium aluminates hydrates, ide,

$-450^{\circ} \mathrm{C}-550^{\circ} \mathrm{C}$ : dehydroxylation of calcium hydrox-

$\sim 700^{\circ} \mathrm{C}-850^{\circ} \mathrm{C}$ : decarbonation of $\mathrm{CaCO}_{3}$.

Figures 9-11 show DTA-TG/dTG curves of PET0. As it is shown, the curves can be divided into four major parts, according to different reactions:

$\sim 100^{\circ} \mathrm{C}-145^{\circ} \mathrm{C}$ : dehydration of pore water,

$\sim 225^{\circ} \mathrm{C}-230^{\circ} \mathrm{C}$ : dehydration of calcium aluminates hydrates,

$\sim 440^{\circ} \mathrm{C}-540^{\circ} \mathrm{C}$ : the reduction of the intensity of the peak corresponding to dehydroxylation of portlandite, which indicates that, with exposure all the $\mathrm{Ca}(\mathrm{OH})_{2}$ that was formed reacted with the $\mathrm{HCl}$ acid solutions (Equation (3)).

$\sim 700^{\circ} \mathrm{C}-850^{\circ} \mathrm{C}$ : decarbonation of $\mathrm{CaCO}_{3}$.

All the weight loss data are expressed as a function of the ignited weight of the sample, as suggested by Taylor [53]. The calcium hydroxide content was determined from the following equation:

$$
C H(\%)=W L_{C H}(\%) \times \frac{M W_{C H}}{M W_{H}}
$$

where $\mathrm{CH}(\%)$ is the content of $\mathrm{Ca}(\mathrm{OH})_{2}$ (in weight basis), $W L_{C H}(\%)$ is the weight loss occurred during the dehydration of calcium hydroxide (in weight basis), $M W_{C H}$ is the molar weight of calcium hydroxide and $M W_{H}$ is the molar weight of water.

When one attacks the PET0 composite by the hydrochloric acid at $0.5 \%, 1 \%$ and $1.5 \%$, there is a diminution of the calcium hydroxide $(\mathrm{CH})$ content, as can be seen in Figure 12. Because when the concentration of acid increases, there is less formation of portlandite $\mathrm{Ca}(\mathrm{OH})_{2}$, which is mainly consumed following the chemical reaction (Equation (3)). This is confirms our previous results.

\subsubsection{Scanning Electron Microscope (SEM) Observations}

In case of $\mathrm{HCl}$ attack, the damaged of PET0 composite was selected as an example to observe the microstructure of deterioration and the SEM images are shown in Figure 13. No portlandite crystal exists in the acid attacked composite. It is clear that exposure to solution of hydrochloric acid generates pores and micro-cracks in the mortar specimens. So, The SEM and ATD-TG/dTG analyses corroborate some of the results discussed above.

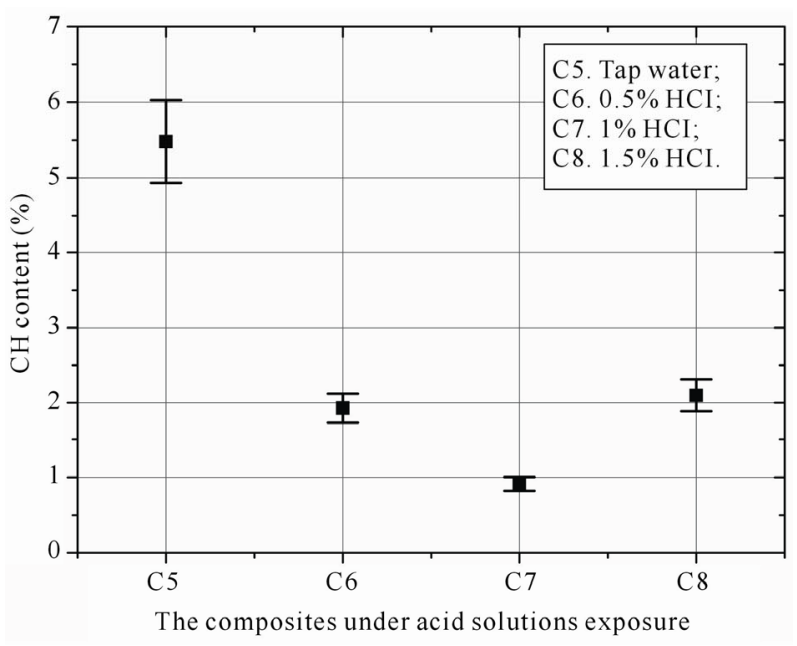

Figure 12. Effect of $\mathrm{HCl}$ acids concentration on the calcium hydroxide content $(\mathrm{CH})$.

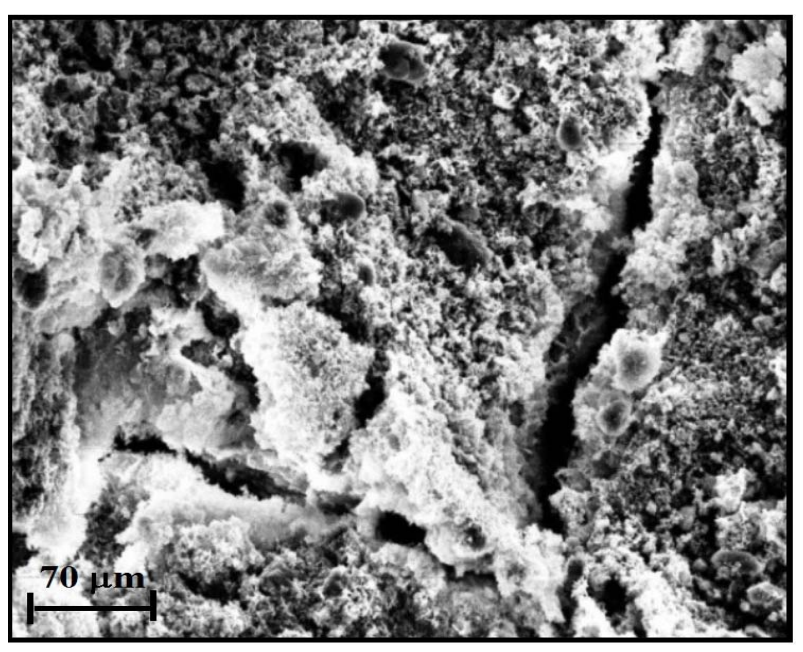

Figure 13. SEM images obtained for the external porous texture of PET0 sample after being attacked by the $1 \%$ hydrochloric acid solution $(\times 600)$.

\subsection{Ammonium Chloride $\mathrm{NH}_{4} \mathrm{Cl}$ Attack}

Figures 14 and 15 show the evolution of the degraded thickness of composite immersed in a solution of ammonium chloride $10 \%$, represented as a function of the polymer-cement ratios. Loss of mass followed the same trend. At 480 days, significant differences were obtained: compared to PET0, the depth of attack was $16.2 \%$, $26.2 \%$ and $34.8 \%$ lower for PET2.5, PET5 and PET7.5, respectively.

Ammonium salts are generally more destructive than salts of other bases [54]. So, ammonium chloride is very aggressive and reacts following an exchange mechanism $2 \mathrm{NH}_{4}^{+} \rightarrow \mathrm{Ca}^{2+}$ given by the reaction:

$$
\begin{aligned}
& \mathrm{Ca}(\mathrm{OH})_{2}+2 \mathrm{NH}_{4} \mathrm{Cl} \rightarrow \mathrm{CaCl}_{2}+2 \mathrm{H}_{2} \mathrm{O}+\mathrm{NH}_{3} \text { gas } \\
& \left(\mathrm{NH}_{4} \mathrm{OH}=\mathrm{H}_{2} \mathrm{O}+\mathrm{NH}_{3} \text { gas }\right)
\end{aligned}
$$




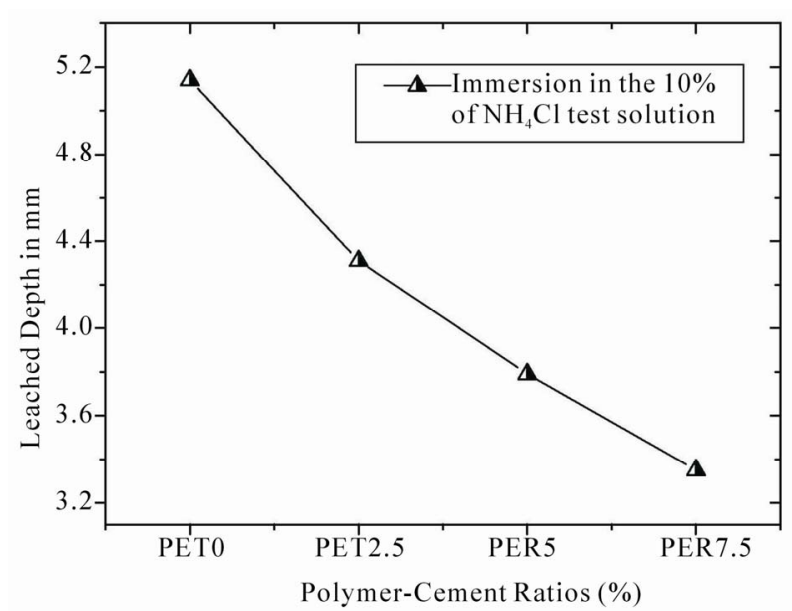

Figure 14. Depth of attack due to the leaching of composite immersed in $10 \%$ ammonium chloride.

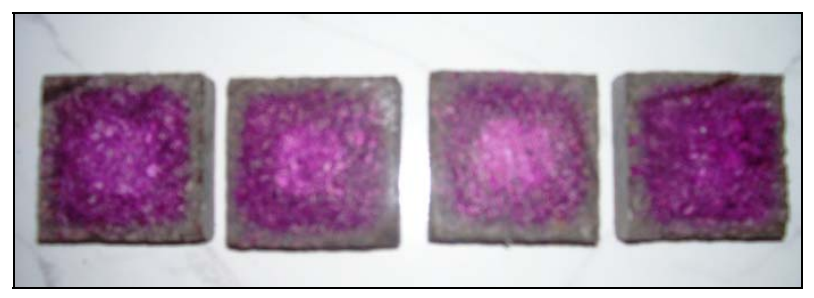

Figure 15. Depth of reduced lixiviation of the composites PET0, PET2.5, PET5 and PET7.5 (from the left to right) indicated by the phenolphthalein solution.

This reaction leads to the formation of a highly soluble calcium chloride $\left(46.08 \mathrm{~g} / 100 \mathrm{ml}\right.$ of $\left.\mathrm{H}_{2} \mathrm{O}\right)$ and a release of ammonia. The resulting reduction of the $\mathrm{pH}$ impedes the reaction to reach a state of equilibrium. The conesquence is progressive leaching of portlandite and C-S-H, thus leading to a decrease of the mechanical properties of mortar. The reaction with aluminates leads to the formation of a hydrated calcium chloride aluminate $3 \mathrm{CaO} \cdot \mathrm{Al}_{2} \mathrm{O}_{3} \cdot \mathrm{CaCl}_{2} \cdot 10 \mathrm{H}_{2} \mathrm{O}$ [55].

As for most of the other tests, the composites were the modified mortar most resistant to this acid attack $(\mathrm{pH}=$ 5.6). This might be due to impervious PET granules blocking the passage of the aggressive solutions and the reduction of the sorptivity of modified mortar (Tables 3 and 4). Furthermore, the decrease in porosity due to the incorporation of PET in composite [48] contributes to reduce the absorption of acidic solution accompanied by a reduction of loss in weight. However, no pertinent data were found concerning the effect of PET against ammonium chloride attack.

\subsection{Ammonium Sulfate $\left(\mathrm{NH}_{4}\right)_{2} \mathrm{SO}_{4}$ and $\mathrm{H}_{2} \mathrm{SO}_{4}$ Attacks}

Figure 16 shows the percentage change with respect to time in the weight of cubes immersed in sulfuric acid and

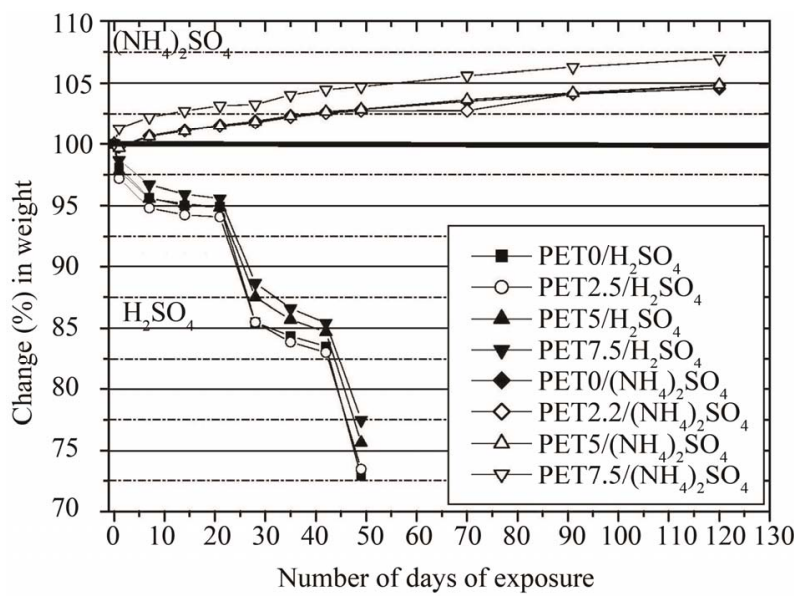

Figure 16. Change (\%) in weight with time under $\mathrm{H}_{2} \mathrm{SO}_{4}$ acid and $\left(\mathrm{NH}_{4}\right)_{2} \mathrm{SO}_{4}$ solutions.

ammonium-sulfate. It can be seen in the same figure that there is an increase in weight of cubes immersed in ammonium sulfate for the period of experimentation. The augmentation in weight after 120 days of immersion was $4.5 \%, 4.8 \%, 4.86 \%$ and $6.9 \%$ for PET0, PET2.5, PET5 and PET7.5 respectively. However, in the cubes immersed in sulfuric acid it can be noted that the reduction in weight has occurred. So, the rate of reduction in weight was less in PET5 and PET7.5. The mass loss for PET7.5 is lower than the corresponding PET0 mortar by 5\% (Figure 16).

The increase in the weight of composites immersed in sulfatic solutions can be explained by the formation of expansive products. In the presence of water, the sulfates ions react with calcium aluminates hydrate $\left(\mathrm{C}_{3} \mathrm{~A}\right)$ and/or the components of the calcium hydroxide of hardened cement paste to form calcium sulfoaluminate hydrate commonly called "ettringite" [56] and calcium sulfate (gypsum). However, it is important to recognize that the end products of the various reactions, if they occur so as to damage the mortar or concrete, result in different types of damage [57]. Mehta [58] reported that the 5\% $\left(\mathrm{NH}_{4}\right)_{2} \mathrm{SO}_{4}$ solution proved to be more aggressive than $1 \% \mathrm{H}_{2} \mathrm{SO}_{4}$; it appears that ammonium salts are able to decompose the calcium hydrate, which is the principal solid phase in hydrated portland cement pastes. In consequence, different preventive measures are required.

Compressive strength losses CSL\% of PET-composites samples after curing in water for 28 days and exposed in $10 \%$ of ammonium-sulfate solution for 860 days and in $5 \%$ of sulfuric acid for 56 days are presented in Figure 17. It can be seen that the modified mortar samples containing polyethylene therephtalate have better behaviour in ammonium-sulfate solution. The results indicate that the resistance to $\left(\mathrm{NH}_{4}\right)_{2} \mathrm{SO}_{4}$ solution of the composites was increased with an increase in PET content. At day-860, the CSL\% of PET2.5, PET5 and 


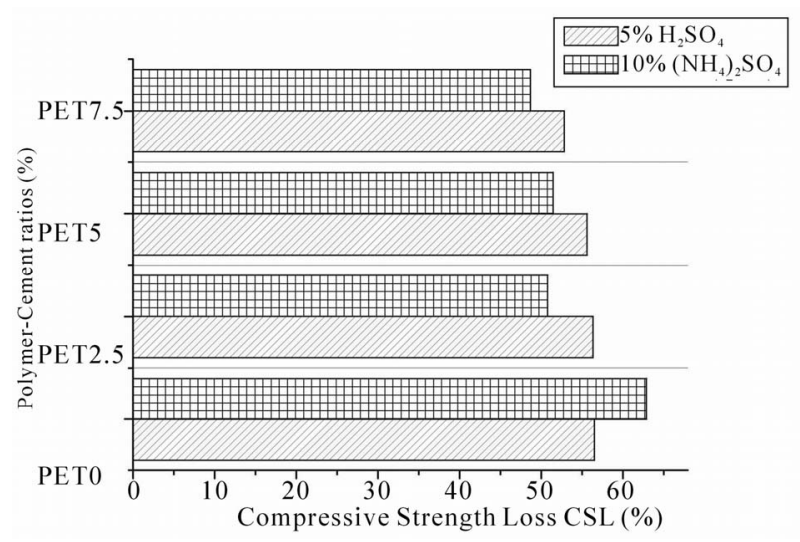

Figure 17. Compressive strength loss of specimens under $\mathrm{H}_{2} \mathrm{SO}_{4}$ acid and $\left(\mathrm{NH}_{4}\right)_{2} \mathrm{SO}_{4}$ solutions exposure.

PET7.5 were reduced by $19.2 \%, 18.2 \%$ and $22.6 \%$, respectively, when compared to that of PET0. In addition, at 56 days, there is a $C S L \%$ diminution around $7 \%$ for PET7.5 compared to an unmodified one in sulfuric acid solution (Figure 17).

Therefore, the increase in the resistance to ammonium-sulfate of the composites is attributed to the impervious PET granules blocking the passage of the aggressive solution and the reduction of the sorptivity of polymer-mortar (Tables 3 and 4). Consequently, the decrease in porosity due to the incorporation of PET in modified mortars [48] contributes to reduce the absorption of sulfates solution. These results are in agreement with those reported elsewhere [46]. The same explanation was also done for the PET7.5 in the sulfuric acid. Additionally, different teams of researchers [49-51] reported that the incorporation of organic additions (polymers) increases chemical resistance in aggressive media.

It can be concluded that adding PET to blended portland cement makes this cement become more resistant to the ammonium-sulfate aggressive environment. It is evident that the resistance of cement to sulfate aggression is also related to the content of $\mathrm{C}_{3} \mathrm{~A}$ in them [27]. However, no pertinent data were found concerning the effect of PET against ammonium sulfate attack.

Ammonium sulfate is very aggressive and reacts following an exchange mechanism $2 \mathrm{NH}_{4}^{+} \rightarrow \mathrm{Ca}^{2+}$ given by the reaction:

$$
\begin{aligned}
& \mathrm{Ca}(\mathrm{OH})_{2}+\left(\mathrm{NH}_{4}\right)_{2} \mathrm{SO}_{4} \\
& \rightarrow \mathrm{CaSO}_{4}+2 \mathrm{H}_{2} \mathrm{O}+2 \mathrm{NH}_{3} \text { gas. } \\
& \left(\mathrm{NH}_{4} \mathrm{OH}=\mathrm{H}_{2} \mathrm{O}+\mathrm{NH}_{3} \text { gas }\right)
\end{aligned}
$$

This reaction leads to the formation of less watersoluble gypsum $\mathrm{CaSO}_{4}, 0.241 \mathrm{~g} / 100 \mathrm{ml}$ of $\mathrm{H}_{2} \mathrm{O}$ and a release of ammonia. Calcium sulfate formed as described above can subsequently react with $\mathrm{C}_{3} \mathrm{~A}$, usually via the formation of mono-sulfoaluminate, to form ettringite (Equation (5)). In addition, attack of hydrated Portland cement by $\mathrm{H}_{2} \mathrm{SO}_{4}$ acid is two-fold. The first one is by acid attack or hydrogen ions and the second is by the sulfuric ions. Two salts are formed: namely calcium sulfate and ettringite (Equations (4) and (5)). These are destructive salts and the pressure produced during their formation causes mortar to crack and disintegrate.

Comparing the exposure of mortars to sulfuric acid and ammonium sulfate, it is immediately apparent that the mechanisms involved are quite different. So, Rendell et al. [59] reported that sulfuric acid causes a heavy deposition of gypsum that acts as a protective layer; this surface protection is verified by the unchanged hardness beyond a depth of $2 \mathrm{~mm}$, however, it is noted that gypsum is deposited at depths of up to $2 \mathrm{~mm}$ in fissures and voids. In this case the mechanism of attack is caused by the production of the expansive gypsum, this expansive effect being responsible for the progressive opening of the material structure by dislocation of surface material. It was noted from the SEM and microanalysis [59], that there is a filling of fissures and pores with gypsum, this deposition will have the effect of producing an internal blocking of the pore structure. It is, therefore, proposed that the surface deposit of gypsum, if not removed by scour forms a protective layer thus limiting the attack rate.

The samples exposed to ammonium sulfate experienced a significant deterioration in material hardness up to a depth of $5 \mathrm{~mm}$ [59]. However, from the microanalysis it was noted that there was little sulfur evident behind the surface; the major site of gypsum formation being at the surface. It is proposed that the mechanism of deterioration in this case is one of dissolution of $\mathrm{Ca}^{2+}$ from the mortar. Leaching of $\mathrm{Ca}^{2+}$ is principally the result of the dissolution of portlandite; this action causes an opening of the pore structure of the mortar and is, therefore, responsible for the reduction in mechanical strength and ultimate loss in durability [59].

\subsubsection{Visual Inspection}

Additionally, in case of $\mathrm{H}_{2} \mathrm{SO}_{4}$ and $\left(\mathrm{NH}_{4}\right)_{2} \mathrm{SO}_{4}$ attacks, the damaged of PET0 composite was selected as an example to observe the macrostructure of deterioration. So, these results are confirmed by the change of surface samples before and after immersion in the aggressive solutions. A visual inspection of specimens as shown in Figure 18 revealed the deterioration of the samples, particularly for the mortars immersed in sulfuric acid. These mortars kept their cubic forms more or less, but their dimensions decreased considerably.

Photos of specimens stored in the ammonium sulfate solution for 120 and 860 days are presented in Figure 18. The samples stored for 120 days under ammonium sulfate exposure showed the first signs of deterioration, while the specimens stored in tap water did not show any 


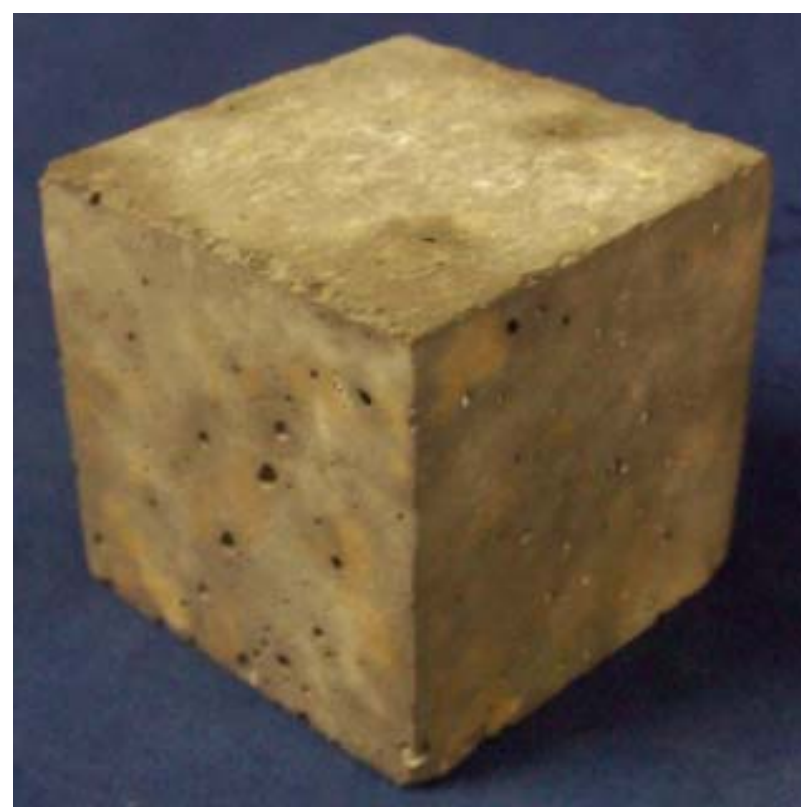

(a)

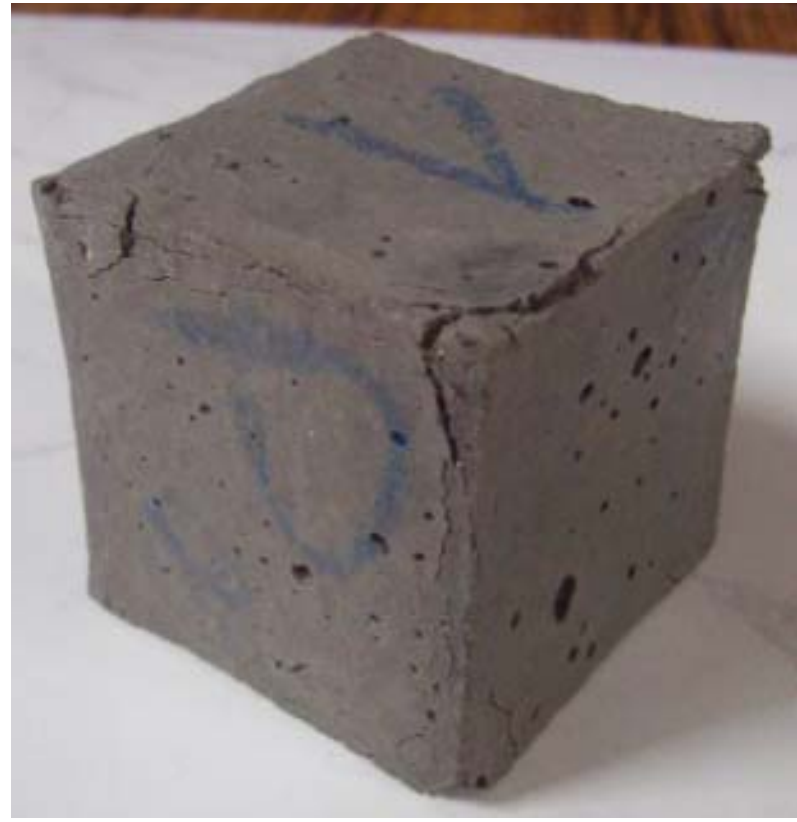

(c)

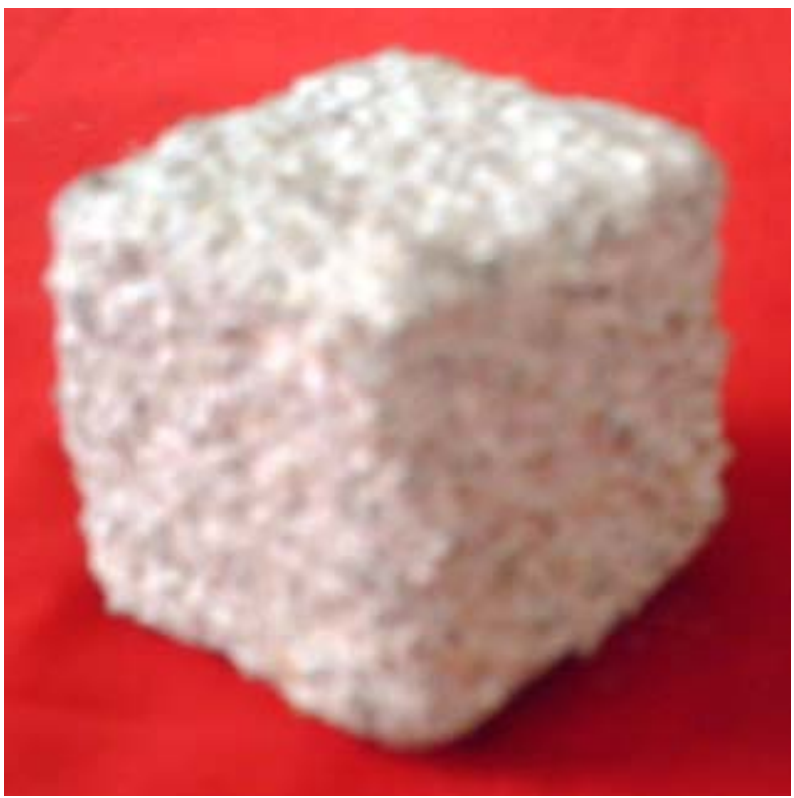

(b)

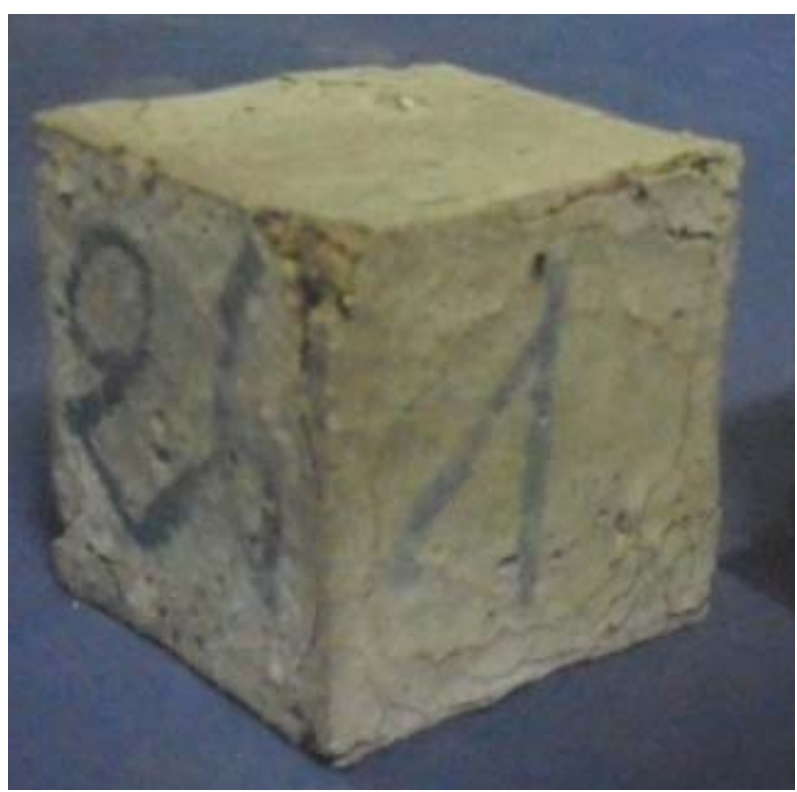

(d)

Figure 18. Specimens cubes $(50 \mathrm{~mL})$ exposed to: (a) Tap water, (b) $\mathrm{H}_{2} \mathrm{SO}_{4}\left(56\right.$ days), (c) $\left(\mathrm{NH}_{4}\right)_{2} \mathrm{SO}_{4}\left(120\right.$ days), (d) $\left(\mathrm{NH}_{4}\right)_{2} \mathrm{SO}_{4}$ (860 days).

clear evidence of attack. The discussion below concerns the samples stored in $\left(\mathrm{NH}_{4}\right)_{2} \mathrm{SO}_{4}$ solution. In all cases, the first sign of attack was the deterioration of the corners, followed by cracking along the edges. Progressively, expansion and spalling took place on the surface of the specimens.

After 860 days of immersion in a solution of $10 \%$ $\left(\mathrm{NH}_{4}\right)_{2} \mathrm{SO}_{4}$, all 4 surfaces of the specimens developed a white cover that was friable and started to peel off, leaving the aggregates uncovered and reducing the connec- tivity of the paste. Thus, the extent of surface deterioration after 860 days of exposure had a tendency to decrease with the increased replacement level of the PET wastes.

Polymer-mortar composites modified with PET waste can be advantageous for special applications where the main request is not for mechanical properties, such as in the production of sound barriers and cement blocks for lightweight concrete walls. Also, these composites are often used as low-cost materials for preventing chemical 
attacks or repairing various reinforced concrete structures damaged by chloride-induced corrosion [21,22], as well as in structures exposed to aggressive environments where high resistance to ammonium-sulfate/-chloride, acid, basic and chloride solutions is required.

\subsubsection{X-Ray Diffraction (XRD) Analysis}

Figure 19 presents the XRD analysis of PET0 composite, as an example, before and after attack by different sulfuric acid and ammonium sulfate solutions. The common factor for all hydrated samples is the presence of portlandite $\mathrm{Ca}(\mathrm{OH})_{2}$ and ettringite

$\mathrm{Ca}_{6} \mathrm{Al}_{2}\left(\mathrm{SO}_{4}\right)_{3}(\mathrm{OH})_{12} \cdot 26 \mathrm{H}_{2} \mathrm{O}$. Unlike thesam ples from the sulfuric acid and ammonium sulfate solution which are marked by considerable quantities of gypsum $\left(\mathrm{CaSO}_{4} \cdot 2 \mathrm{H}_{2} \mathrm{O}\right)$, the samples which were in water contain minimal quantity of gypsum. As gypsum existed in the initial material in both cases, it is evident that during the process of hydration it served, together with other components, to form ettringite, for water cured samples.

Opposite to this, the quantity of formed ettringite is small and similar in all the samples exposed to ammonium sulfate, which points out to the assumption that mostly sulfate ions only from gypsum present in the initial samples participated in the forming of ettringite. These results are in agreement with those reported by Miletic et al. [27]. We also noted that portlandite $\mathrm{Ca}(\mathrm{OH})_{2}$ was completely decomposed by different acid and sulfate solutions following the chemical reactions 4,5 and 8 .

\subsubsection{FT-IR Analyses}

Table 6 illustrates the positions and intensities of infrared absorption bands and Figures 20 and 21 show the FT-IR patterns of specimens exposed to: Tap water, $\mathrm{H}_{2} \mathrm{SO}_{4}$, and $\left(\mathrm{NH}_{4}\right)_{2} \mathrm{SO}_{4}$. The FT-IR spectra of the composite hydrated up to 28 days and cured in water are presented in Figure 20 and Table 6. The major changes of

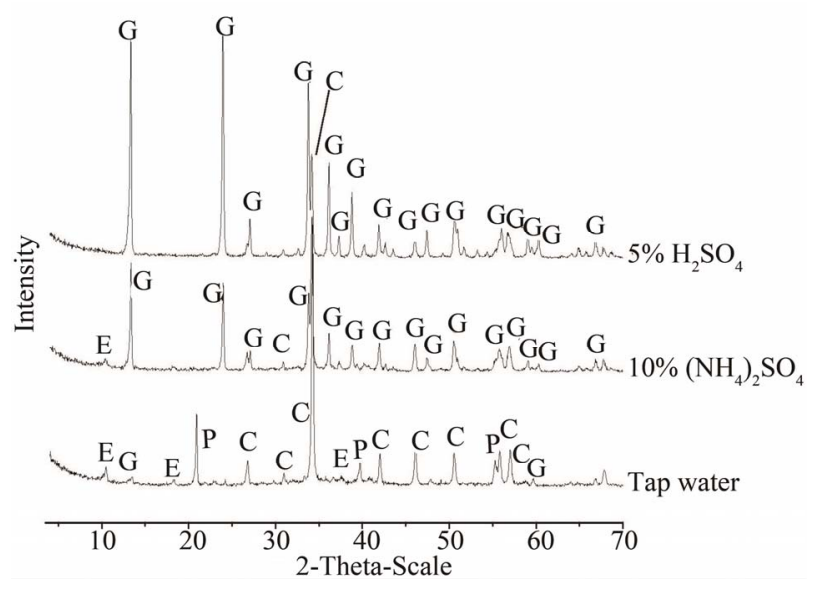

Figure 19. $\mathrm{X}$-ray diffraction pattern of the specimens under $\mathrm{H}_{2} \mathrm{SO}_{4}$ acid and $\left(\mathrm{NH}_{4}\right)_{2} \mathrm{SO}_{4}$ solutions exposure. $\mathrm{P}$ : portlandite $\mathrm{Ca}(\mathrm{OH})_{2}$; E: ettringite; $\mathrm{C}$ : calcite; G: gypsum. the FT-IR spectra in the hydrated cement pastes are: Calcium hydroxide bands $\left(\sim 3637 \mathrm{~cm}^{-1}\right)$ and also for the free $\mathrm{OH}$ groups, combined and adsorbed water of $\mathrm{CSH}$, AFm and AFt phases $\left(3452 \mathrm{~cm}^{-1}\right)$, molecular water (3425-3445 and $\left.1641-1660 \mathrm{~cm}^{-1}\right)$, carbonate phases

$\left(\sim 1428,874.5\right.$ and $\left.712.5 \mathrm{~cm}^{-1}\right)$. The broad band at $\sim 990$ - $1020 \mathrm{~cm}^{-1}$ arises from C-S-H vibrations, in agreement with those reported by Martinez-Ramirez [52].

As the same for the X-ray diffraction, the FT-IR analysis of composites after attack by acid and sulfate solutions (Table 6, Figures 20 and 21) confirms the appearance of a large quantity of gypsum

$\left(\mathrm{CaSO}_{4} \cdot 2 \mathrm{H}_{2} \mathrm{O}\right)$ on the specimens exposed to $\mathrm{H}_{2} \mathrm{SO}_{4}$ and $\left(\mathrm{NH}_{4}\right)_{2} \mathrm{SO}_{4}$ and a small quantity of ettringite on the specimens exposed to ammonium sulfate.

Therefore, in Table 6 and Figures 20 and 21 no absorption bands corresponding to calcium hydroxide were detected in all of specimens exposed to acidic and ammonium sulfate solutions, which is in agreement with XRD analysis. The $\mathrm{Ca}(\mathrm{OH})_{2}$ was consumed by aggressive solutions following the chemical reactions 4,5 and 8 .

To obtain further evidence to corroborate these observations from XRD and FT-IR, further investigation was made using SEM, DSC and TG/dTG analyses.

\subsubsection{Scanning Electron Microscope (SEM) Observations}

The composite of PET0 exposed to $\left(\mathrm{NH}_{4}\right)_{2} \mathrm{SO}_{4}$ solutions was selected as an example to observe the microstructure of deterioration products, and the SEM images are shown in Figure 22. No portlandite $\mathrm{Ca}(\mathrm{OH})_{2}$ crystal existed in the sulfate-attacked unmodified mortar, and many club-shaped or needle-like crystals were embedded irregularly in the pulpy material with a very open microstructure. Figure 22(a) shows a large number of needlelike ettringite crystals, smaller than $2 \mu \mathrm{m}$ in diameter and $10-11 \mu \mathrm{m}$ in length, and the existence of different morphologies of the C-S-H gel in the specimen covering the mortar surface before sulfation. In the pores or surface cracks, there were many club-shaped gypsum crystals, which had much larger sizes (smaller than $100-200 \mu \mathrm{m}$ in diameter and $300-500 \mu \mathrm{m}$ in length) than the ettringite, as shown in Figure 22(b). The formation of both ettringite and gypsum led to the cracking, spalling, and decomposition of the unmodified mortar exposed to a sulfate environment (Figure 22(c)). The combination of XRD, FT-IR and SEM led to the positive identification of the deterioration products' formation.

The surface that was exposed to sulfuric acid had a nature that was quite different. The scanning electron microscopy (SEM) observations were also carried out to identify the products formed by attack of PET0 in the 
Table 6. Fourier-transform infrared table of composite before and after attack by different acid and sulfate solutions, in KBr pellet.

\begin{tabular}{|c|c|c|c|c|c|}
\hline \multicolumn{6}{|c|}{ Positions and Intensities of Infrared Absorption Bands (FT-IR) } \\
\hline$\left(\mathrm{cm}^{-1}\right)$ & Group & Compounds & Tap water & $\mathrm{H}_{2} \mathrm{SO}_{4}$ & $\left(\mathrm{NH}_{4}\right)_{2} \mathrm{SO}_{4}$ \\
\hline$\sim 3000-3600$ & $\mathrm{H}_{2} \mathrm{O}, \mathrm{OH}$, hydrogen bonds & Gypsum, CSH & ++ & + & + \\
\hline$\sim 3637.09$ & $\mathrm{H}_{2} \mathrm{O}, \mathrm{OH}$, hydrogen bonds & portlandite & ++ & 0 & 0 \\
\hline $3424-3452$ & $\mathrm{H}_{2} \mathrm{O}, \mathrm{OH}$ & $\mathrm{AFm}, \mathrm{AFt}$ & + & + & ++ \\
\hline $1623-1660$ & $\mathrm{H}_{2} \mathrm{O}, \mathrm{OH}$ & $\mathrm{H}_{2} \mathrm{O}$ & + & + & + \\
\hline $1428-1439$ & $v \mathrm{C}-\mathrm{O}$ & $\mathrm{CaCO}_{3}$ (Calcite) & + & + & + \\
\hline $873-875$ & $v \mathrm{C}-\mathrm{O}$ & $\mathrm{CaCO}_{3}$ (Calcite) & + & + & + \\
\hline $710-713$ & $v \mathrm{C}-\mathrm{O}$ & $\mathrm{CaCO}_{3}$ (Calcite) & + & + & + \\
\hline$\sim 990-1020$ & $v \mathrm{Si}-\mathrm{O}$ & $\mathrm{CSH}$ vibrations & + & $+(\mathrm{w}, \mathrm{sh})$ & + \\
\hline$\sim 1130-1142$ & $v \mathrm{~S}-\mathrm{O}$ & Gypsum & $\sim$ & +++ & +++ \\
\hline$\sim 604.5-672$ & $\delta \mathrm{S}-\mathrm{O}$ & Gypsum & $\sim$ & +++ & +++ \\
\hline$\sim 3408-3546$ & $v \mathrm{O}-\mathrm{H}$ & water (Gypsum) & $\sim$ & +++ & +++ \\
\hline$\sim 1622-1687$ & $\delta \mathrm{O}-\mathrm{H}$ & water (Gypsum) & $\sim$ & +++ & +++ \\
\hline$\sim 1105-1110$ & $\delta$ S-O (sulfates) & Ettringite & + & 0 & $\sim$ \\
\hline$\sim 602-608$ & $\delta$ S-O (sulfates) & Ettringite & + & 0 & $\sim$ \\
\hline 2982 & $v \mathrm{C}-\mathrm{O}$ (harmonic bands) & $\mathrm{CaCO}_{3}$ (Calcite) & + & + & + \\
\hline 2872 & $v$ C-O (harmonic bands) & $\mathrm{CaCO}_{3}$ (Calcite) & + & + & + \\
\hline$\sim 2515$ & v C-O (harmonic bands) & $\mathrm{CaCO}_{3}$ (Calcite) & + & + & + \\
\hline$\sim 1798$ & $v$ C-O (harmonic bands) & $\mathrm{CaCO}_{3}$ (Calcite) & + & + & + \\
\hline
\end{tabular}

w: weak, sh: shoulder, $\mathrm{AFt}: \mathrm{C}(\mathrm{A}, \mathrm{F}) \cdot 3 \mathrm{CaSO}_{4} \cdot 32 \mathrm{H}_{2} \mathrm{O} ; \mathrm{AFm}: \mathrm{C}_{3} \mathrm{~A} \cdot 3 \mathrm{CaSO}_{4} \cdot 12 \mathrm{H}_{2} \mathrm{O}$.

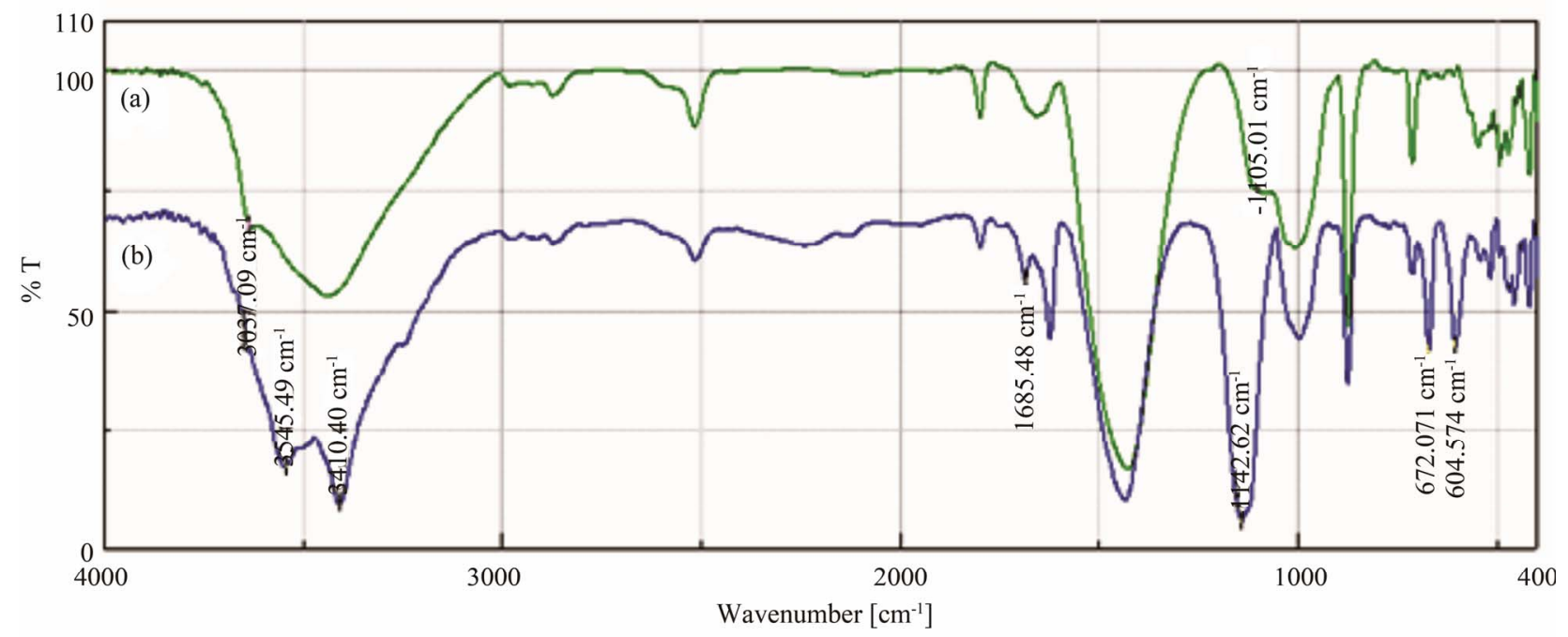

Figure 20. FT-IR spectra of the specimens under (a) Tap water and (b) $\left(\mathrm{NH}_{4}\right)_{2} \mathrm{SO}_{4}$ solution exposure. 


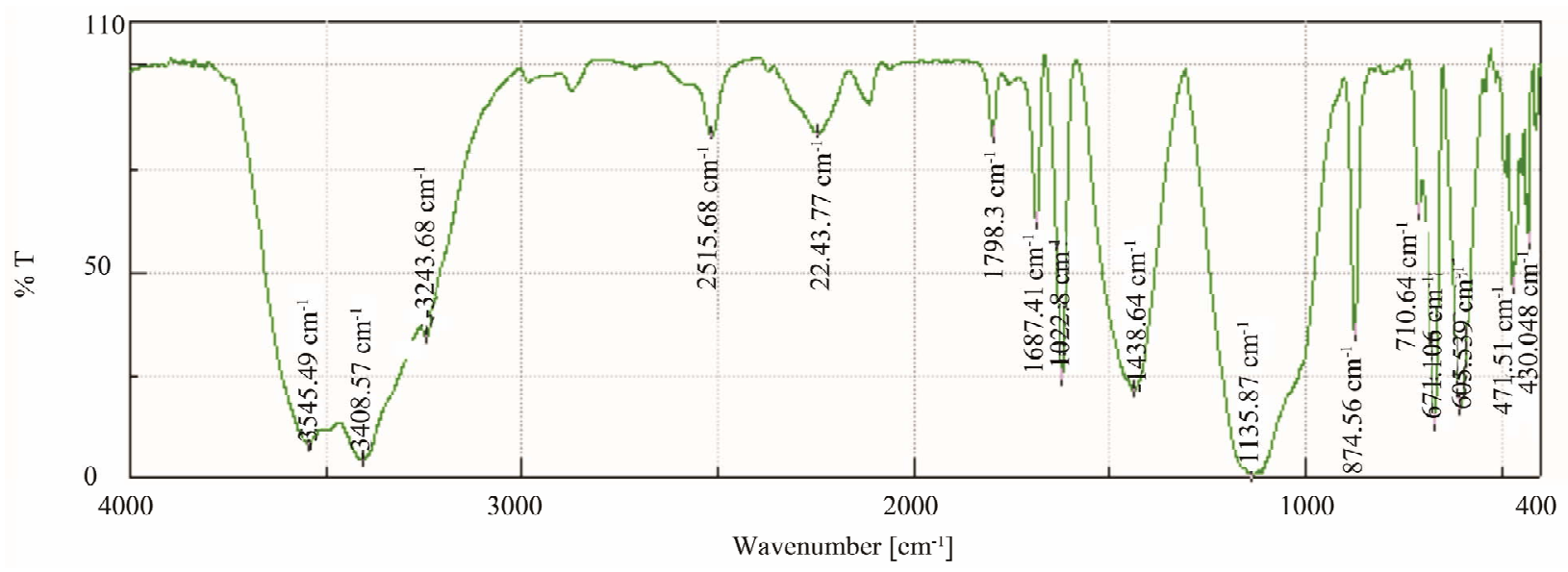

Figure 21. FT-IR spectra of the specimens under sulfuric acid exposure.

sulfuric acid solutions and the results are exhibited in Figure 23. In addition, Figure 23 taken around a crack on the surface of the core sample shows deposition of a large number of needle-like crystals (gypsum), smaller than $36-40 \mu \mathrm{m}$ in diameter and $300-500 \mu \mathrm{m}$ in length, covering the mortar surface. In the pores or surface cracks, there are many club-shaped gypsum crystals as shown in Figure 23. The formation of gypsum leads to the cracking, spalling, and decomposition of mortar exposed to sulfuric acid environment. The SEM images obtained by SEM corroborate some of the results discussed above.

Consequently, our results are in agreement with those reported by Rendell et al. [59] which showed that when cement mortar is exposed to sulfuric acid a dense layer of gypsum is formed; this is capable of retarding the deterioration process by acting as a surface sealing layer. Gypsum also exists in pores and fissures in the surface zone, indicating that the attack is due to expansive crystallisation. In ammonium sulfate the surface deposit of gypsum is sparse and the damage to the concrete occurs to a greater depth. The lack of sulfur found in the surface zone indicates that the mechanism of deterioration is due to the dissolution of $\mathrm{Ca}^{2+}$.

\subsubsection{DSC and TG/dTG Analyses}

The DSC and TG/dTG curves of PET0 composite before and after $\left(\mathrm{NH}_{4}\right)_{2} \mathrm{SO}_{4}$ solution and $\mathrm{H}_{2} \mathrm{SO}_{4}$ acid attack are presented in Figures 24-26.

Figure 24 shows the DSC curves of unmodified mortar PET0 in the tap water. It can be seen that DSC curves for this mortar consist of three zones:

$\sim 90^{\circ} \mathrm{C}-115^{\circ} \mathrm{C}$ : dehydration of pore water $(\mathrm{CSH}$, ettringite),

$\sim 145^{\circ} \mathrm{C}-157^{\circ} \mathrm{C}$ : dehydration of calcium sulphate (Gypsum),

$\sim 450^{\circ} \mathrm{C}-500^{\circ} \mathrm{C}$ : dehydroxylation of calcium hydroxide, portlandite.
Figure 25 presents the DSC trace of PET0 after ammonium sulphate attack; it displays four endothermic peaks, according to different reactions:

$\sim 100^{\circ} \mathrm{C}-145^{\circ} \mathrm{C}$ : dehydration of pore water,

$$
\begin{gathered}
\sim 115^{\circ} \mathrm{C}-120^{\circ} \mathrm{C} \text { : ettringite } \\
\mathrm{Ca}_{6}\left[\mathrm{Al}(\mathrm{OH})_{6}\right]_{2}\left(\mathrm{SO}_{4}\right)_{3} \cdot 26 \mathrm{H}_{2} \mathrm{O},
\end{gathered}
$$

$\sim 140^{\circ} \mathrm{C}-145^{\circ} \mathrm{C}$ : the intensity of the peak due to calcium sulphate $\mathrm{CaSO}_{4} \cdot 2 \mathrm{H}_{2} \mathrm{O}$ is greater. So, gypsum was the dominant reaction product (Equation (8)) while the ettringite appeared as a trace element in the composite.

$\sim 440^{\circ} \mathrm{C}-510^{\circ} \mathrm{C}$ : In PET0 composite there was no endothermic peak at $462^{\circ} \mathrm{C}$, which indicates that, with exposure all the $\mathrm{Ca}(\mathrm{OH})_{2}$ that was formed reacted with the ammonium sulphate solution.

Figure 26 presents the TG/dTG trace for the surface part of the sample obtained from the PET0 composite stored in 5\% sulphuric acid solution; it displays three endothermic peaks at 157 (High intensity), 210 and $850^{\circ} \mathrm{C}-900^{\circ} \mathrm{C}$, indicating gypsum, calcium monocarpboaluminate hydrated and decarbonation of the calcite $\mathrm{CaCO}_{3}$. Also, TG/dTG analysis showed no endothermic peak at $462^{\circ} \mathrm{C}$, which indicates that, with exposure all the $\mathrm{Ca}(\mathrm{OH})_{2}$ that was formed reacted with the sulphuric acid solution (Equation (4)).

Hence, the DSC, TG/dTG curves obtained by DSC and TG/dTG analyses corroborate some of the results discussed above.

It should be pointed out that, in practice, the durability of composites exposed to the chemical solutions investigated in this study should be much better than indicated by the test data given here. First, because the chemical solutions of high concentrations used in the test are not commonly encountered in food and most other industries. Second, the composite specimens in the test were fully submerged, whereas in the industrial practice the structural element such as floor is usually exposed to attack 


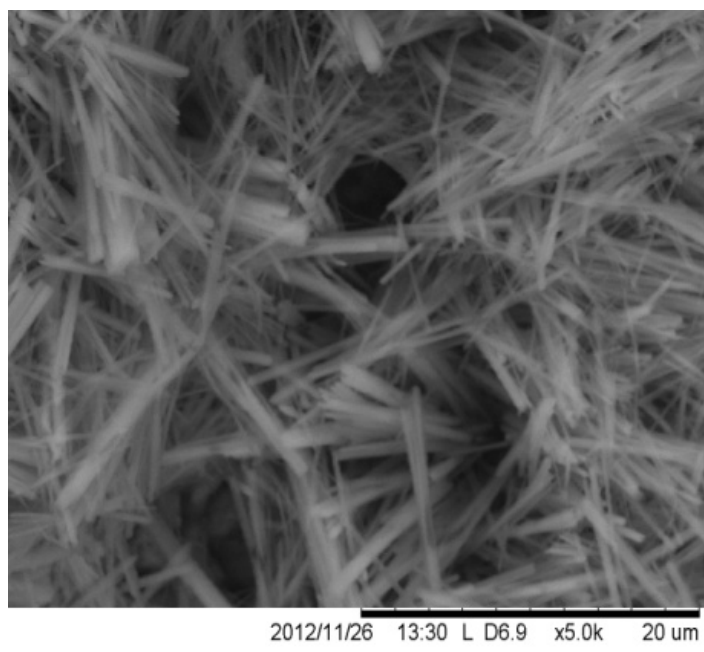

(a)

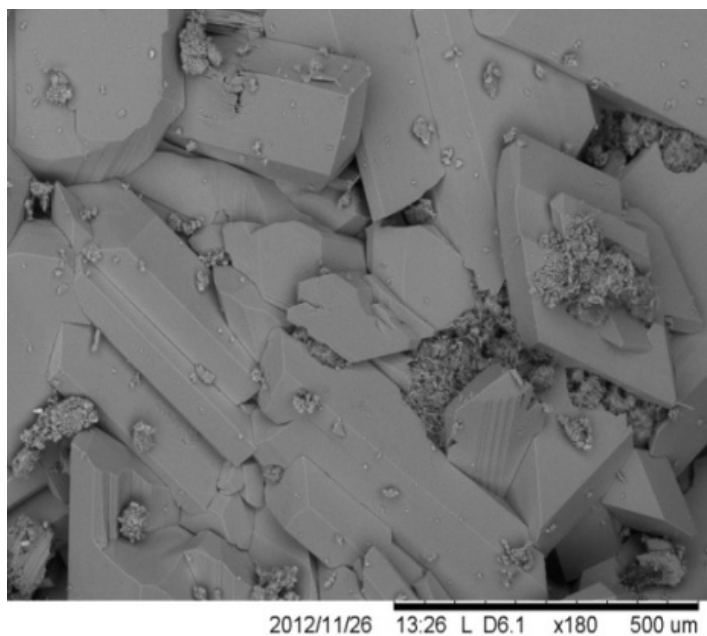

(b)

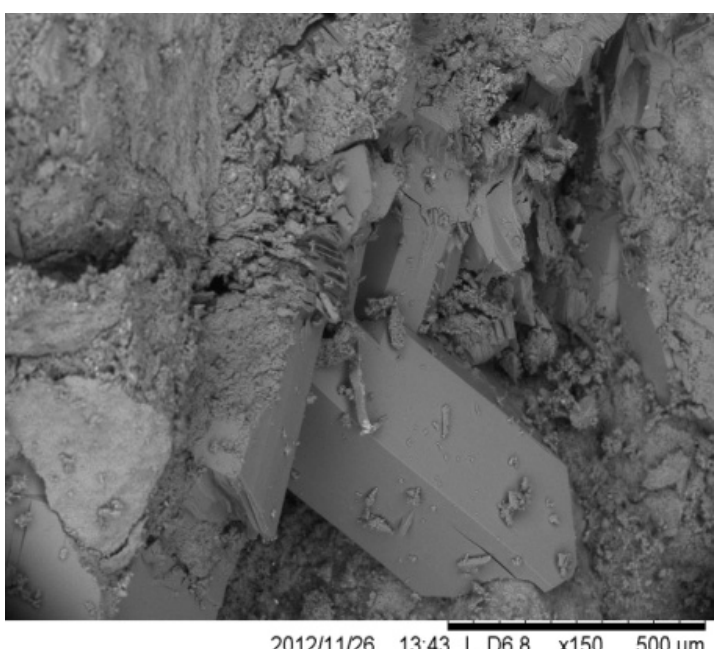

(c)

Figure 22. SEM photos of the PETO composite after exposure to $10 \%\left(\mathrm{NH}_{4}\right)_{2} \mathrm{SO}_{4}$ solution for 860 days; (a) Needlelike ettringite crystals, (b) Club-shaped gypsum crystals and (c) deteriorate mortar.

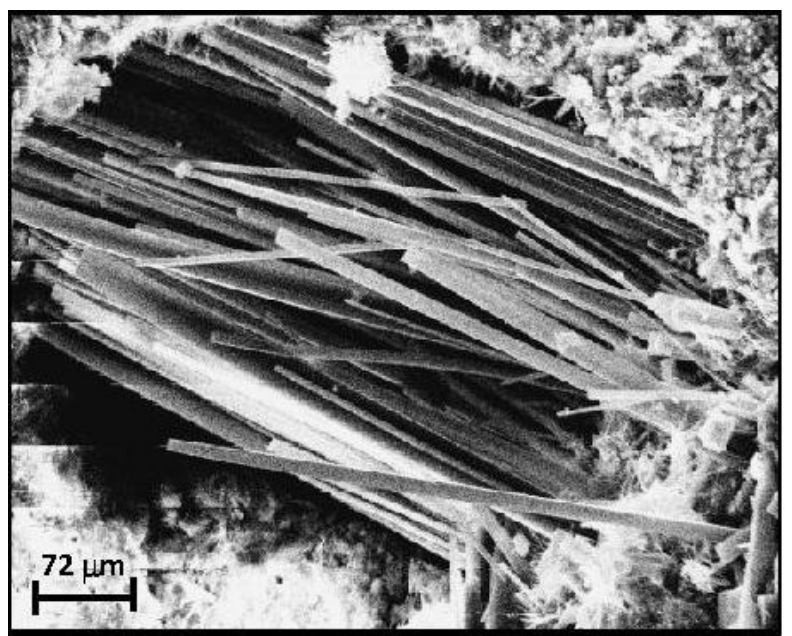

Figure 23. SEM photos of the PETO composite after exposure to $5 \% \mathrm{H}_{2} \mathrm{SO}_{4}$ solution $(\times 600)$ for 56 days; needle-like crystals (gypsum) in the pore.

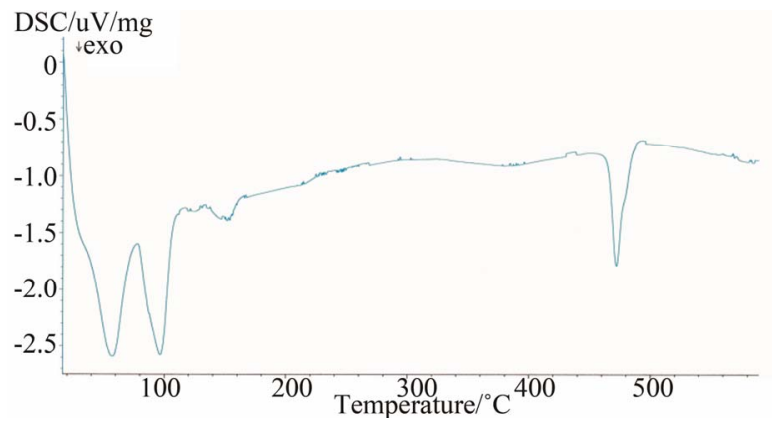

Figure 24. DSC curves at $10 \mathrm{~K} / \mathrm{min}$ of composite PET0 in tap water exposure.

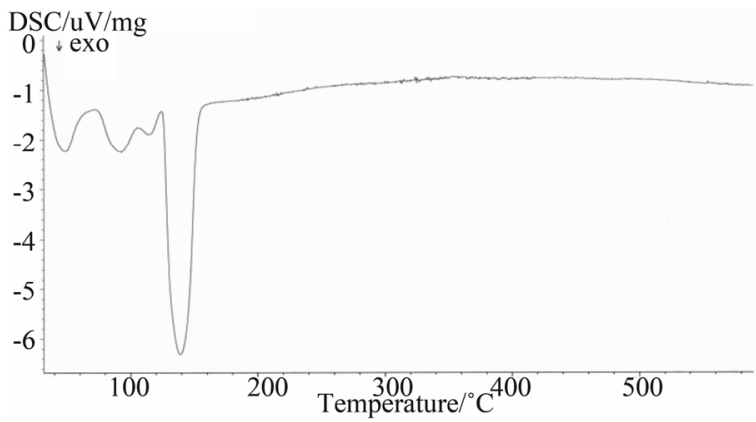

Figure 25. DSC curves at $10 \mathrm{~K} / \mathrm{min}$ of composite PET0 in $\left(\mathrm{NH}_{4}\right)_{2} \mathrm{SO}_{4}$ solution exposure.

from one side only. Third, the immersion solutions were kept in state of constant motion, and were frequently replaced which fresh brushing of the specimens once every week; this removed the reaction products and almost continuously forced new material to come into contact with aggressive solution.

\section{Conclusions}

The influence of the PET particles on PET-modified 


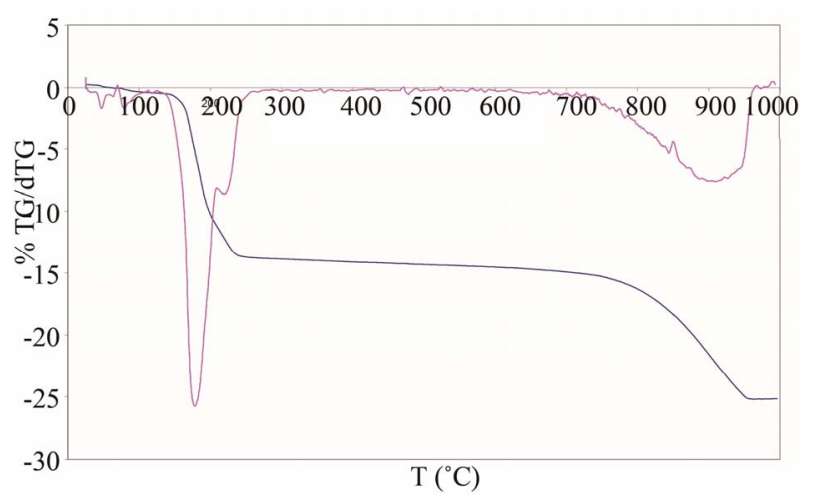

Figure 26. TG/dTG curves at $10 \mathrm{~K} / \mathrm{min}$ of composite PET0 in $\mathrm{H}_{2} \mathrm{SO}_{4}$ acid exposure.

mortar composites sorptivity, mechanical strength and the chemical properties under hydrochloric acid, ammonium-chloride, ammonium-sulfate and sulfuric acid attack solutions were determined. The results of testing the attack by aggressive solutions allow the following conclusions:

1) Test results of the hydraulic transport properties revealed that the addition of PET particles tends to restrict water propagation in the cement matrix and reduces water absorption of the composite. The decrease of the sorptivity-value is favorable to the durability of the specimen structures.

2) The results of specific indicators for ammonium chloride, ammonium-sulfate and acid attacks showed that an increase in the PET content led to better resistance of the composite. This may to the reduced volume of largesized pores and the improved resistance to the absorption of aggressive solutions with the addition of PET in the cement pastes, because of the impervious PET particles blocking the passage of the aggressive ions. In addition, to the reduction in the porosity near particle/matrix interfacial zone, due to the high bonding between PET additive and cement paste.

3) Among composite mixes in the $\mathrm{HCl}$ acid attacks, PET7.5 mixes perform better than other mixes. The chemical resistance characteristics of materials are affected by the concentration and by the nature of acids following the order: $0.5 \% \mathrm{HCl}<1.0 \% \mathrm{HCl}<1.5 \% \mathrm{HCl}$. Additionally, from the simultaneously traced DTA/TG curves there is a diminution of the calcium hydroxide $(\mathrm{CH})$ content, because of the formation of calcium chloride which has a high solubility in water.

4) On the basis of the XRD, FT-IR and DSC analyses of the changes in the phase composition, it can be concluded that the main product of the ammonium-sulfate corrosion of cement is gypsum, accompanied by ettringite. The common factor for all hydrated samples is the presence of portlandite $\mathrm{Ca}(\mathrm{OH})_{2}$ and ettringite $\mathrm{Ca}_{6} \mathrm{Al}_{2}\left(\mathrm{SO}_{4}\right)_{3}(\mathrm{OH})_{12} \cdot 26 \mathrm{H}_{2} \mathrm{O}$. The samples exposed to the ammonium-sulfate solution show considerable quantities of gypsum $\mathrm{CaSO}_{4} \cdot 2 \mathrm{H}_{2} \mathrm{O}$. The quantity of ettringite formed is small and very similar in all the samples, which points out to the assumption that mostly sulfate ions only from gypsum present in the initial samples participated.

5) The SEM results show that the presence of sulfur ions is virtually existent in the matrix of composites exposed to ammonium sulfate. It is proposed that the reduction in mechanical hardness can be attributed to a migration of $\mathrm{Ca}^{2+}$ from the outer layers of the unmodified mortar.

6) The mechanism of attack in the case of composite exposed to sulfuric acid is principally a surface phe- nomenon, the expansive action of the gypsum acting to dislocate aggregate and to increase micro cracking at the surface. It is evident from the SEM that there is a filling of pores and micro fissures with gypsum (Tg/dTG). In the absence of erosion this layer has a surface blocking ability.

The utilization of the PET waste particles as a binder instead of cement in the manufacture of PET-mortar composites and as a sustainable building materials in the construction industry help to preserve natural resources and maintain the ecological balance and also to prevent or repair various reinforced concrete structures.

\section{Acknowledgements}

The authors acknowledge the financial support from the Ministry of Higher Education and Scientific Research of Algeria, under the grants CNEPRU J0405520120005. The authors greatly appreciated the technical support from the Laboratory of LUSAC EA 2607, University of Caen Basse-Normandie, Cherbourg Octeville (French) and also would like to thank Mr M. T. Gouasmi and the graduate students, Mrs. A. Herizi and A. Kerour for their help.

\section{REFERENCES}

[1] S. Miletić, M. Ilić, J. Ranogajec, R. Marinovič-Neducin, and M. Djurić, "Portland Ash Cement Degradation in Ammonium-Sulfate Solution," Cement and Concrete Research, Vol. 28, No. 5, 1998, pp. 713-725. doi:10.1016/S0008-8846(98)00023-4

[2] Y. Ohama, "Polymer Based Admixtures," Cement and Concrete Composite, Vol. 20, No. 2-3, 1998, pp. 189-212. doi:10.1016/S0958-9465(97)00065-6

[3] Y. Ohama, "Hand Book of Polymer-Modified Concrete and Mortars, Properties and Process Technology," Noyes Publications, Park Ridge, 1995, p. 236.

[4] D. W. Fowler, "Polymers in Concrete: A Vision for the 21st Century," Cement and Concrete Composites, Vol. 21, No. 5-6, 1999, pp. 449-452. doi:10.1016/S0958-9465(99)00032-3 
[5] N. Saikia and J. de Brito, "Use of Plastic Waste as Aggregate in Cement Mortar and Concrete Preparation: A review," Construction and Building Materials, Vol. 34, 2012, pp. 385-401.

doi:10.1016/j.conbuildmat.2012.02.066

[6] R. Siddique, J. Khatib and I. Kaur, "Use of Recycled Plastic in Concrete: A review," Waste Management, Vol. 28, No. 10, 2008, pp. 1835-1852. doi:10.1016/j.wasman.2007.09.011

[7] K. F. Portella, A. Joukoski, R. Franck and R. Derksen, "Reciclagem Secundária de Rejeitos de Porcelanas Elétricas em Estruturas de Concreto: Determinação do Desempenho sob Envelhecimento Acelerado," Cerâmica, Vol. 52, No. 323, 2006, pp. 155-167. doi:10.1590/S0366-69132006000300008

[8] I. Guerra, I. Vivar, B. Llamas, A. Juan and J. Moran, "Eco-efficient Concretes: The Effects of Using Recycled Ceramic Material from Sanitary Installations on The Mechanical Properties of Concrete," Waste Management, Vol. 29, No. 2, 2009, pp. 643-646. doi:10.1016/j.wasman.2008.06.018

[9] Z. Z. Ismail and E. A. Al-Hashmi, "Use of Waste Plastic in Concrete Mixture as Aggregate Replacement," Waste Management, Vol. 28, No. 11, 2008, pp. 2041-2047.

[10] S. C. Angulo, C. Ulsen, V. M. John, H. Kahn and M. A. Cincotto, "Chemical-Mineralogical Characterization of C\&D Waste Recycled Aggregates from São Paulo, Brazil," Waste Management, Vol. 29, No. 2, 2009, pp. 721730.

[11] C. Hoppen, K. F. Portella, A. Joukoski, E. M. Trindade and C. V. Andreóli, "Uso de Lodo de Estação de Tratamento de Agua Centrifugado, em Matriz de Concreto de Cimento Portland para Reduzir o Impacto Ambiental," Química Nova, Vol. 29, No. 1, 2006, pp. 79-84.

[12] K. S. Rebeiz, "Time-Temperature Properties of Polymer Concrete Using Recycled PET," Cement and Concrete Composites, Vol. 17, No. 2, 1995, pp. 119-124. doi:10.1016/0958-9465(94)00004-I

[13] YW. Choi, DJ. Moon, YJ. Kim, M. Lachemi, "Characteristics of Mortar and Concrete Containing Fine Aggregate Manufactured from Recycled Waste Polyethylene Terephthalate Bottles," Construction and Building Materials, Vol. 23, No. 8, pp. 2829-2835. doi:10.1016/j.conbuildmat.2009.02.036

[14] Y. W. Choi, D. J. Moon, J. S. Chung and S. K. Cho, "Effects of PET Waste Bottles Aggregate on the Properties of Concrete," Cement and Concrete Research, Vol. 35, No. 4, 2005, pp. 776-781. doi:10.1016/j.cemconres.2004.05.014

[15] B. JO, G. Tae and C. Kim, "Uniaxial Creep Behavior and Prediction of Recycled-PET Polymer Concrete," Construction Building Materials, Vol. 21, 2007, pp. 15521559. doi:10.1016/j.conbuildmat.2005.10.003

[16] T. Ochi, S. Okubo and K. Fukui, "Development of Recycled PET Fiber and Its Application as Concrete Reinforcing Fiber," Cement and Concrete Composites, Vol. 29, No. 6, 2007, pp. 448-455.

doi:10.1016/j.cemconcomp.2007.02.002
[17] A. Khaloo, M. Dehestani and P. Rahmatabadi, "Mechanical Properties of Concrete Containing a High Volume of Tire-Rubber Particles," Waste Management, Vol. 28, No. 12, 2008, pp. 2472-2482. doi:10.1016/j.wasman.2008.01.015

[18] J. C. A. Galvão, K. F. Portella, A. Joukoski, R. Mendes and E. S. Ferreira, "Use of waste polymers in concrete for repair of dam hydraulic surfaces," Construction and Building Materials, Vol. 25, No. 2, 2011, pp. 1049-1055. doi:10.1016/j.conbuildmat.2010.06.073

[19] R. Wang and C. Meyer, "Performance of Cement Mortar Made With Recycled High Impact Polystyrene," Cement \& Concrete Composites, Vol. 34, No. 9, 2012, pp. 975981. doi:10.1016/j.cemconcomp.2012.06.014

[20] V. Corinaldesi, A. Mazzoli, G. Moriconi, "Mechanical Behaviour and Thermal Conductivity of Mortars Containing Waste Rubber Particles," Materials and Design, Vol. 32, No. 3, 2011, pp. 1646-1650. doi:10.1016/j.matdes.2010.10.013

[21] A. S. Benosman, H. Taibi, M. Mouli, M. Belbachir and Y. Senhadji, "Diffusion of Chloride Ions in Polymer-Mortar Composites (PET)," Journal of Applied Polymer Science, Vol. 110, No. 3, 2008, pp. 1600-1605. doi:10.1002/app.28587

[22] A. S. Benosman, H. Taïbi, M. Belbachir, I. Bahlouli, M. Mouli, Y. Senhadji and D. Houivet, "Resistance of Polymer (PET)-Mortar Composites to Chloride Penetration," Proceedings of 7th Asian Symposium on Polymers in Concrete ASPIC 2012, Istanbul, 3-5 October 2012, pp. 387-395.

[23] M. T. Gouasmi, A. S. Benosman, H. Taibi, M. Belbachir and Y. Senhadji, "Elaboration and Characterization of Polymer-Siliceous Sand Composites," 2nd French Meeting on Insulating Materials RFMI-2, Oran, 17-19 December 2012.

[24] M. T. Gouasmi, "Effects of Polyethylene Terephthalate Lightweight Aggregates on the Properties of Mortar," Magister Thesis, University of Oran, Oran, 2013, p. 153.

[25] "ECO PET," 2007. http://www.ecopet.eu/Domino_english/ecopet.htm

[26] The Korea Institute of Resources Recycling, "The Korean Institute of Resources Recycling, Recycling Handbook," The Korea Institute of Resources Recycling, Seoul, 1999.

[27] S. Miletić, M. Ilić, S. Otović, R. Folić and Y. Ivanov, "Phase Composition Changes Due to Ammonium-Sulphate: Attack on Portland and Portland Fly Ash Cements," Construction and Building Materials, Vol. 13, No. 3, 1999, pp. 117-127. doi:10.1016/S0950-0618(99)00017-3

[28] H. F. W. Taylor, "Crystal Structure of Some Double Hydroxide Minerals," Mineraogicall Magazine, Vol. 39, No. 304, 1973, pp. 247-256. doi:10.1180/minmag.1973.039.304.01

[29] S. Miletić, M. Ilić, J. Ranogajec and M. Djurić, "Sulphate Corrosion of Portland Cement and Portland Cement Mixed With Fly Ash and Slag as a Function of its Composition," Proceedings of XVI Symposuim on Nordic Concrete Research, Helsinki, 1996, pp. 339-340.

[30] S. Miletić and M. Ilić, "Sulphate Corrosion of Portland 
Cement with Various Mineral Compositions, Proceedings of the 13th International Corrosion Congress, Melbourne, 1996, pp. 1-7.

[31] V. Zivica and A. Bajza, "Acidic Attack of Cement Based Materials-A Review. Part 1. Principle of Acidic Attack," Construction and Building Materials, Vol. 15, No. 8, 2001, pp. 331-340. doi:10.1016/S0950-0618(01)00012-5

[32] P. K. Mehta, "Concrete, Properties and Materials," Prentice-Hall, Upper Saddle River, 1986.

[33] W. H. Gutt and W. H. Harrison, "Chemical Resistance of Concrete,” Concrete, Vol. 11, No. 5, 1997, pp. 35-37.

[34] V. Zivica and A. Bajza, "Acidic Attack of Cement-Based Materials-A Review Part 2. Factors of Rate of Acidic Attack and Protective Measures," Construction and Building Materials, Vol. 16, 2002, pp. 215-222. doi:10.1016/S0950-0618(02)00011-9

[35] A. S. Benosman, H. Taïbi, M. Belbachir, I. Bahlouli, M. Mouli, Y. Senhadji and D. Houivet, "Mineralogical Study of Polymer-Mortar Composites with PET Polymer by Means of Spectroscopic Analyses," Materials Sciences and Applications, Vol. 3, No. 3, 2012, pp. 139-150. doi:10.4236/msa.2012.33022

[36] EN 196-3, "Methods of Testing Cement-Part 3: Determination of Setting Time and Soundness," Comité Européen de Normalisation, Brussels, 1995.

[37] EN 196-1, "Methods of testing cement-Part 1: Determination of Strength," Comité Européen de Normalisation, Brussels, 1995.

[38] ASTM C 267-97, "Standard Test Methods for Chemical Resistance of Mortars, Grouts, and Monolithic Surfacing and Polymer Concretes," American Society for Testing and Materials (ASTM) International, West Conshohocken, 1997.

[39] ASTM C1012-04, "Standard Test Method for Length Change of Hydraulic-Cement Mortars Exposed to a Sulfate Solution," American Society for Testing and Materials (ASTM) International, West Conshohocken, 2004.

[40] C. Carde, G. Escadeillas and R. François, "Use of Ammonium Nitrate Solution to Simulate and Accelerate the Leaching of Cement Pastes due To Deionized Water," Magazine Concrete Research, Vol. 181, No. 49, 1997, pp. 295-301. doi:10.1680/macr.1997.49.181.295

[41] N. Kaid, M. Cyr, S. Julien and H. Khelafi, "Durability of Concrete Containing a Natural Pozzolan as Defined by a Performance-Based Approach," Construction and Building Materials, Vol. 23, No. 12, 2009, pp. 3457-3467. doi:10.1016/j.conbuildmat.2009.08.002

[42] Z. T. Chang, X. J. Song, R. Munn, M. Marosszeky, "Using Limestone Aggregates and Different Cements for Enhancing Resistance of Concrete to Sulphuric Acid Attack," Cement and Concrete Research, Vol. 35, No. 8, 2005, pp. 1486-1494. doi:10.1016/j.cemconres.2005.03.006

[43] S. Goyal, M. Kumar, D. S. Sidhu and B. Bhattacharjee, "Resistance of Mineral Admixture Concrete to Acid Attack," Journal of Advanced Concrete Technology, Vol. 7, No. 2, 2009, pp. 273-283. doi:10.3151/jact.7.273
[44] H. Siad, H. A. Mesbah, H. Khelafi, S. Kamali-Bernard and M. Mouli, "Effect Of Mineral Admixture on Resistance to Sulphuric and Hydrochloric Acid Attacks in Self-Compacting Concrete," Canadian Journal of Civil Engineering, Vol. 37, No. 3, 2010, pp. 441-449. doi:10.1139/L09-157

[45] D. Achoura, Ch. Lanos, R. Jauberthie and B. Redjel, "Influence d'une Substitution Partielle du Ciment par du Laitier de Hauts Fourneaux Sur la Résistance des Mortiers en Milieu Acide," Journal de Physique IV France, EDP Sciences, Vol. 118, No. 1, 2004, pp. 159-164. doi:10.1051/jp4:2004118019

[46] A. S. Benosman, M. Mouli, H. Taibi, M. Belbachir and Y. Senhadji, "Resistance of Polymer (PET)-Mortar Composites to Aggressive Solutions," International Journal of Engineering Research in Africa, Vol. 5, No. 1, 2011, pp. 1-15. doi:10.4028/www.scientific.net/JERA.5.1

[47] A. Allahverdi and F. Škvára, "Acidic Corrosion of Hydrated Cement Based Materials-Part 1. Mechanism of the Phenomenon," Ceramics-Silikáty, Vol. 44, No. 3, 2000, pp. 114-120.

[48] A. S. Benosman, "Mechanical Performance and Durability of Cementitious Materials Modified by Adding Polymer (PET)," Ph.D. Thesis, University of Oran, Algeria, 2010.

[49] J.-A. Rossignolo, M.-V.C. Agnesini, "Durability of Polymer-Modified Lightweight Aggregate Concrete," Cement and Concrete Composites, Vol. 26, No. 4, 2004, pp. 375-380. doi:10.1016/S0958-9465(03)00022-2

[50] J. Monteny, N. De Belie, E. Vincke, W. Verstraete and L. Taerwe, "Chemical and Microbiological Tests to Simulate Sulfuric Acid Corrosion of Polymer-Modified Concrete," Cement and Concrete Research, Vol. 31, No. 9, 2001, pp. 1359-1365.

[51] S. Chandra and L. Berntsson, "Lightweight Aggregate Concrete-Science, Technology, and Applications," William Andrew Publishing/Noyes, Chapter 8, 2002, pp. 231-240.

[52] S. Martínez-Ramírez, "Influence of $\mathrm{SO}_{2}$ Deposition on Cement Mortar Hydration," Cement and Concrete Research, Vol. 29, No. 1, 1999, pp. 107-111. doi:10.1016/S0008-8846(98)00183-5

[53] H. F. W. Taylor, "Studies on the Chemistry and Microstructures of Cement Pastes," Proceedings of the British Ceramic Society, Vol. 35, 1984, pp. 65-82.

[54] C. L. Page and M. M. Page, "Durability of Concrete and Cement Composites," Woodhead Publishing, Cambidge England, 2007, p. 404.

[55] V. Ukraincik, D. Bjecovic and A. Djurekovic, "Concrete corrosion in a nitrogen fertilizer plant," In: P. J. Seredaand and G. G. Litvan, Eds., Durability of building materi- als and components, ASTM, Philadelphia, 1978, pp. 397-409.

[56] A. Vichot and J.-P. Ollivier, "La durabilité des bétons," Presses de l'École nationale des Ponts et chaussées, ENPC, France, 2008.

[57] A. M. Neville, "The Confused World of Sulfate Attack on Concrete," Cement and Concrete Research, Vol. 34, No. 
8, 2004, pp. $1275-1296$.

doi:10.1016/j.cemconres.2004.04.004

[58] P. K. Mehta, "Studies on Chemical resistance of low water/cement ratio concretes," Cement and Concrete Research, Vol. 15, No. 6, 1985, pp. 969-978. doi:10.1016/0008-8846(85)90087-0

[59] F. Rendell and R. Jauberthie, "The Deterioration of Mortar in Sulphate Environments," Construction and Building Materials, Vol. 13, No. 6, 1999, pp. 321-327.

doi:10.1016/S0950-0618(99)00031-8 